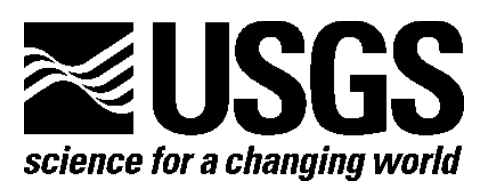

\title{
Uranium in the Wyoming Landscape Conservation Initiative Study Area, Southwestern Wyoming
}

By Anna B. Wilson

Open-File Report 2014-1123

U.S. Department of the Interior U.S. Geological Survey 


\section{U.S. Department of the Interior SALLY JEWELL, Secretary}

\section{U.S. Geological Survey \\ Suzette M. Kimball, Acting Director}

U.S. Geological Survey, Reston, Virginia: 2015

For more information on the USGS-the Federal source for science about the Earth, its natural and living resources, natural hazards, and the environment-visit http://www.usgs.gov/ or call 1-888-ASK-USGS (1-888-275-8747).

For an overview of USGS information products, including maps, imagery, and publications, visit http://www.usgs.gov/pubprod/.

Any use of trade, firm, or product names is for descriptive purposes only and does not imply endorsement by the U.S. Government.

Although this information product, for the most part, is in the public domain, it also may contain copyrighted materials as noted in the text. Permission to reproduce copyrighted items must be secured from the copyright owner.

Suggested citation:

Wilson, A.B., 2015, Uranium in the Wyoming Landscape Conservation Initiative Study Area, southwestern Wyoming: U.S. Geological Survey Open-File Report 2014-1123, 33 p., 1 plate, http://dx.doi.org/10.3133/ofr20141123.

ISSN 2331-1258 (online) 


\section{Contents}

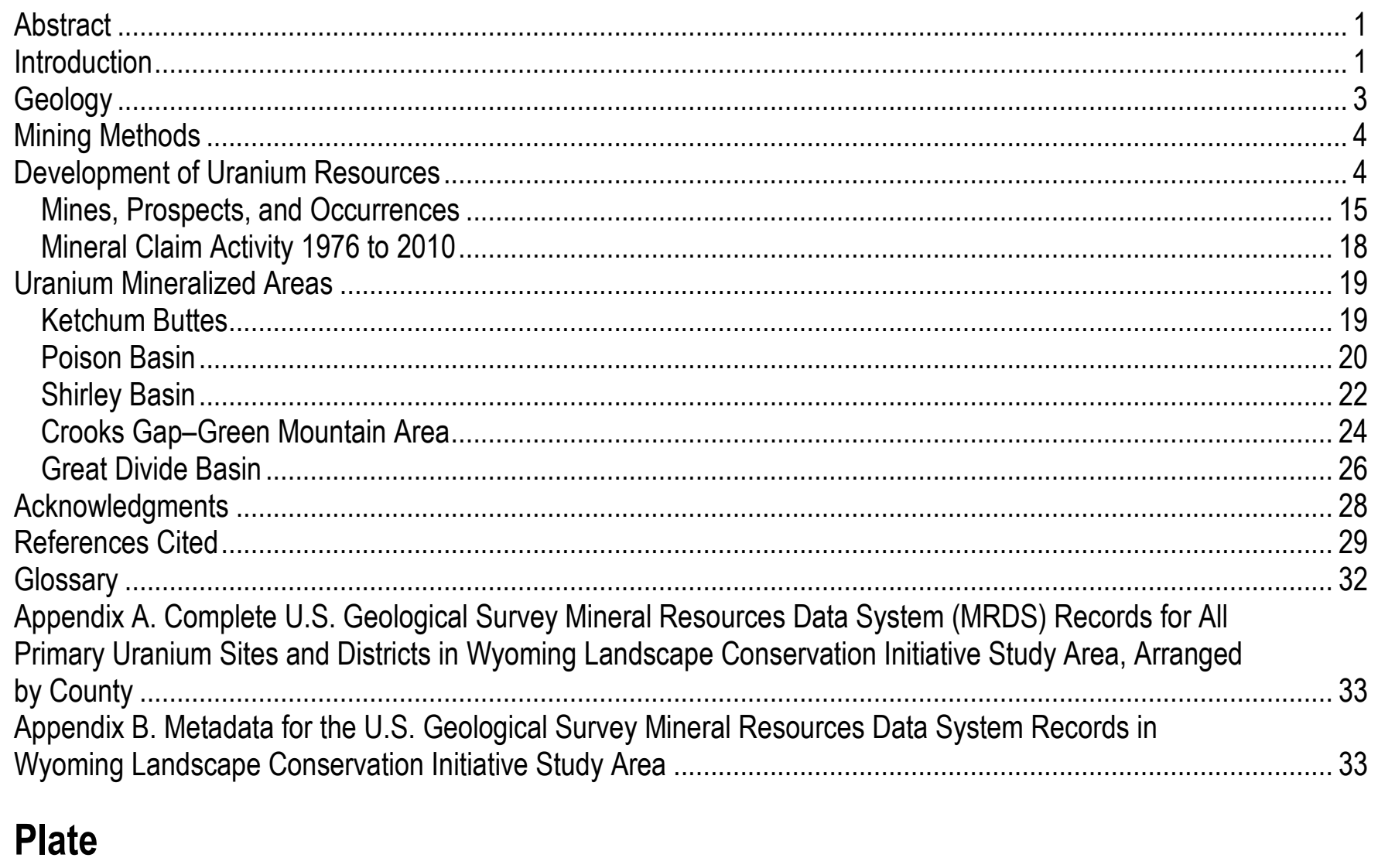

1. Map of uranium mines, prospects, occurrences, and mineralized areas in the Wyoming Landscape Conservation Initiative Study Area, southwestern Wyoming. Scale 1:500,000. link

\section{Figures}

1. Historic $\mathrm{U}_{3} \mathrm{O}_{8}$ production in Wyoming, 1951-2014 2

2. Photograph of waste piles left by uranium mining in Poison Basin, southwestern Wyoming ......................... 5

3. $\quad$ Maps of claim activity at 5-year intervals, 1976-2010, southwestern Wyoming ……................................. 14

4. Photograph of abandoned trench in Poison Basin, southwestern Wyoming........................................... 20

5. Photograph of one of the small underground mines in Poison Basin, southwestern Wyoming .................... 21

6. Photograph of a reclaimed mine site in Shirley Basin, southwestern Wyoming.......................................... 23

7. Photographs of Walker Jenkins Lake, a reclaimed and repurposed open-pit uranium mine in Shirley Basin, southwestern Wyoming ............................................................................................ 24

8. Photograph of Big Eagle mine, Crooks Gap-Green Mountain area, southwestern Wyoming ...................... 26 


\section{Tables}

1. Comparison of production, resources, and endowments of each of the uranium areas ............................. 2

2. List of Mineral Resources Data System records for producers or past producers in the study area and the tonnage of ore produced.

\section{Conversion Factors}

Inch/Pound to SI

\begin{tabular}{lll}
\hline \multicolumn{1}{c}{ Multiply } & By & \multicolumn{1}{c}{ To obtain } \\
\hline inch (in.) & Length & \\
mile (mi) & 2.54 & centimeter $(\mathrm{cm})$ \\
yard (yd) & 1.609 & kilometer $(\mathrm{km})$ \\
\hline & 0.9144 & meter $(\mathrm{m})$ \\
\hline square foot ( $\left.\mathrm{ft}^{2}\right)$ & Area & square centimeter $\left(\mathrm{cm}^{2}\right)$ \\
section $(640$ acres or 1 square mile) & 929.0 & hectare (ha) \\
\hline & 259.0 & \\
\hline pound, avoirdupois $(\mathrm{lb})$ & Mass & kilogram (kg) \\
ton, short $(2,000 \mathrm{lb})$ & 0.4536 & metric ton (tonne, $\mathrm{t})$ \\
\hline
\end{tabular}

SI to Inch/Pound

\begin{tabular}{|c|c|c|}
\hline Multiply & By & To obtain \\
\hline \multicolumn{3}{|c|}{ Length } \\
\hline centimeter $(\mathrm{cm})$ & 0.3937 & inch (in.) \\
\hline kilometer $(\mathrm{km})$ & 0.6214 & mile (mi) \\
\hline \multicolumn{3}{|c|}{ Area } \\
\hline hectare & 0.003861 & section (640 acres or 1 square mile, sq. mi.) \\
\hline \multicolumn{3}{|c|}{ Mass } \\
\hline
\end{tabular}

Horizontal coordinate information is referenced to the North American Datum of 1983 (NAD 83) 


\title{
Uranium in the Wyoming Landscape Conservation Initiative Study Area, Southwestern Wyoming
}

\author{
By Anna B. Wilson
}

\begin{abstract}
Wyoming has led the nation as the producer of uranium ore since 1995 and contains the largest reserves of any state. Approximately one third of Wyoming's total production came from deposits in, or immediately adjacent to, the Wyoming Landscape Conservation Initiative (WLCI) study area in the southwestern corner of the state including all of Carbon, Lincoln, Sublette, Sweetwater, Uinta, and parts of southern Fremont Counties. Conventional open-pit and underground mining methods were employed in the study area until the early 1990s. Since the early 1990s, all uranium mining has been by in-situ recovery (also called in-situ leach). It is estimated that statewide remaining resources of 141,000 tonnes of uranium are about twice the 84,000 tonnes of uranium that the state has already produced.

An evaluation of the mineral commodities present in the WLCI study area that may have a role in the development of southwest Wyoming includes uranium. The WLCI study area contains five uranium mineralized areas: Ketchum Buttes, Poison Basin, Shirley Basin, the southern part of Crooks Gap-Green Mountain, and most of Great Divide Basin. Mineralized areas described in the report and outlined on an accompanying map are based on the presence of either contiguous claim blocks, continuous mineralization adjacent to prospective uranium properties, suggestions of mineralization based on site entries in the U.S. Geological Survey's Mineral Resources Data System (MRDS), or extension of geologic host units or structures. Mineralized areas are not the same as mining districts: the latter have defined administrative boundaries.

In the WLCI study area, all uranium areas except Poison Basin and Ketchum Buttes contain roll-front deposits in Eocene (56-34 Ma) sedimentary rocks. Tabular sandstone-hosted uranium deposits are also recognized within the study area.
\end{abstract}

\section{Introduction}

Wyoming has been the nation's leading producer of uranium ore since 1995 and, according to the Wyoming State Geological Survey, contains the largest uranium reserves of any state (Gregory, 2015). Uranium mining in Wyoming began in the early 1950s and peaked in 1979-1980 (fig. 1) (Gregory, 2015; R.W. Gregory, Wyoming State Geological Survey, unpub. data, August 24, 2015). Since the early 1990s all the state's production has been from in-situ recovery (ISR) (Wyoming State Geological Survey, 2012a). Estimates of total statewide uranium production are on the order of 84,000 tonnes uranium (tU) (Dahlkamp, 2010, p. 149). Remaining known resources are estimated at $141,000 \mathrm{tU}$ at a grade of 0.065 percent uranium (Dahlkamp, 2010, p. 149), or not quite twice what has already been produced. Based on Dahlkamp's estimates, total pre-mining endowment statewide would therefore be about 225,000 tU. Similarly, Finch (2003, p. 4) estimates "reasonably assured resources" of 112,700 tU in Wyoming's basins. Approximately one third of Wyoming's total production came from deposits in or immediately 
adjacent to the Wyoming Landscape Conservation Initiative (WLCI) study area (table 1). The WLCI encompasses most of southwestern Wyoming, including all of Uinta, Lincoln, Sublette, Sweetwater, and Carbon Counties, and only a small portion of southern Fremont County (plate 1).

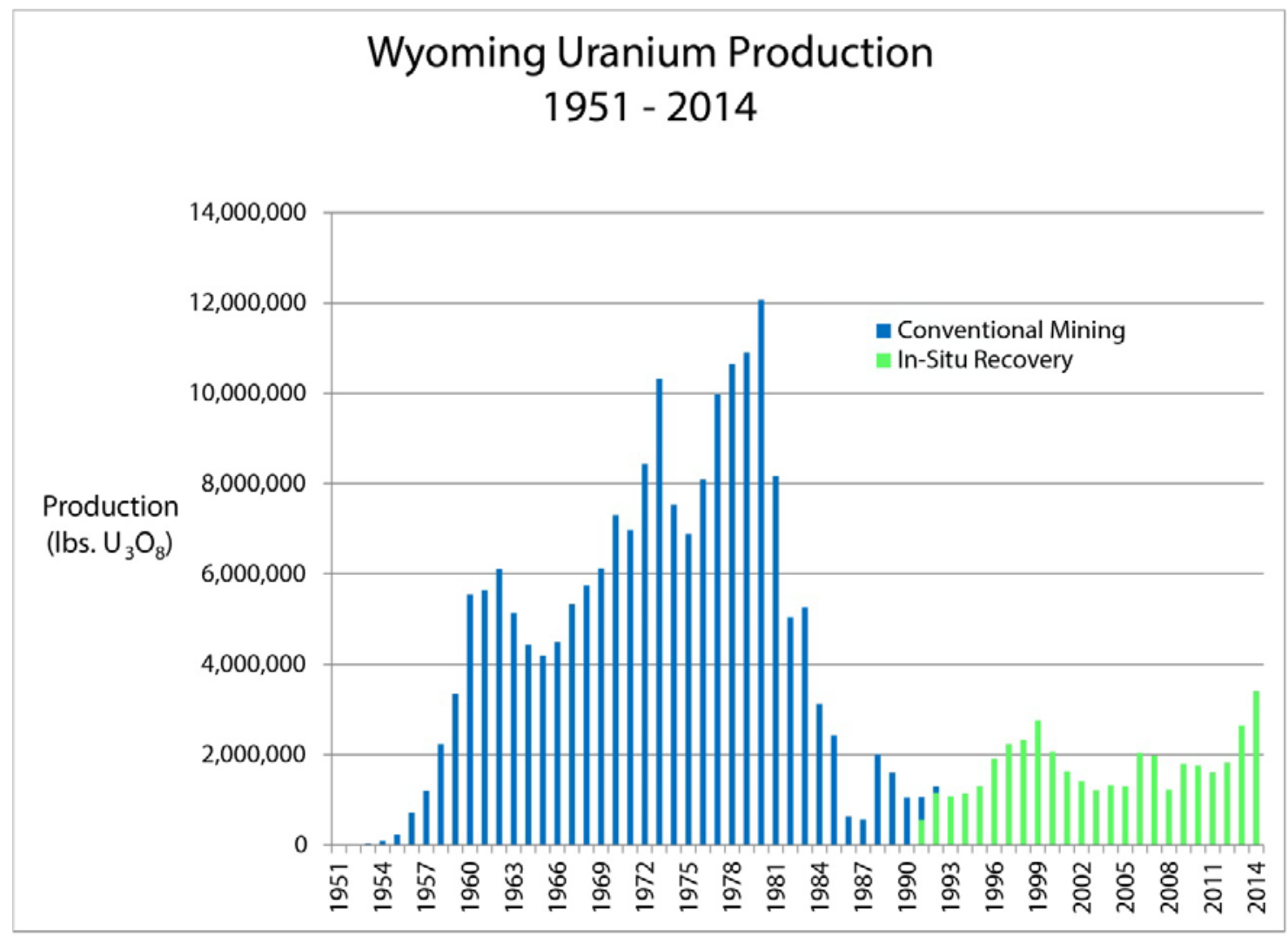

Figure 1. Historic $\mathrm{U}_{3} \mathrm{O}_{8}$ production in thousands of pounds $\mathrm{U}_{3} \mathrm{O}_{8}$ (divide by 2204.623 to convert to metric tons and then multiply by 0.848 to convert from $\mathrm{U}_{3} \mathrm{O}_{8}$ to $\mathrm{U}$ ) from the State of Wyoming. From R.W. Gregory, Wyoming State Geological Survey, unpub. data, August 24, 2015; Wyoming State Geological Survey, 2012b.

Table 1. Comparison of production, resources, and endowments of each of the uranium mineralized areas in the Wyoming Land Conservation Initiative study area.

[Numbers in red were computed by author]

\begin{tabular}{|c|c|c|c|c|c|c|}
\hline Uranium Area & $\begin{array}{l}\text { Production/ } \\
\text { Dahlkamp } \\
(2010) \\
\text { t U }\end{array}$ & $\begin{array}{c}\text { Remaining } \\
\text { resources/ } \\
\text { Dahlkamp } \\
\text { (2010) } \\
\text { t U }\end{array}$ & Resource Grade & $\begin{array}{l}\text { Total Pre-mining } \\
\text { Endowment/ } \\
\text { Dahlkamp } \\
(2010) \\
\text { t U }\end{array}$ & $\begin{array}{c}\text { Production } \\
\text { Gregory and others } \\
(2010) \\
\text { t ore }\end{array}$ & $\begin{array}{c}\text { Reasonably } \\
\text { Assured Resource } \\
\text { Finch } \\
(2003) \\
\text { t U }\end{array}$ \\
\hline$\overline{\text { WYOMING }}$ & 84,000 & 141,000 & & 225,000 & & 112,700 \\
\hline Ketchum Buttes & NA & NA & NA & NA & 1,870 & \\
\hline Poison Basin & 350 & 3,000 & .017 to .17 & 3,350 & 113,254 & \\
\hline Shirley Basin & 18,500 & & 0.07 to 0.5 (mined 0.15 to 0.16 ) & 47,000 & $16,399,033$ & \\
\hline CrooksGap/Green Mtn & 8,000 & 32,000 & 0.12 to 0.25 & 40,000 & $4,388,463$ & \\
\hline Great Divide Basin & & & 0.025 to 0.06 & & $2,544,315$ & \\
\hline Sweetwater+REB + ENQ & 500 & & & 10,000 & & \\
\hline Lost Soldier/Red Desert & & & & 17,230 & & \\
\hline Pard & & & & & 386 & \\
\hline Bison Basin & & 1,600 & 0.04 to 0.06 & 1,600 & & \\
\hline TOTAL for WLCI & 27,350 & & & & $23,447,321$ & \\
\hline
\end{tabular}


Exact resource and production values for Wyoming are unknown. Comparing values reported by Dahlkamp (2010) to Gregory and others (2010) and Boberg (2010) gives only a sense of the relative amount of ore in each of the uranium areas. Dahlkamp (2010) reports resources and production in metric tons (tonnes) uranium (but for ores with a wide range of grades it is not possible to accurately compute the tonnes of ore). Gregory and others (2010) report short tons of ore produced (converted to metric tons uranium for this study), but not grade or amount of contained uranium. Boberg reports reserves and production in metric tons $\mathrm{U}_{3} \mathrm{O}_{8}$ (also converted here to metric tons uranium) but not grade or total tonnage of ore. Some reported quantities are ore and others are the amount of contained metal (or $\mathrm{U}_{3} \mathrm{O}_{8}$ ). The term "Resources," as used here, refers to ore that is discovered and well established. These amounts do not include "undiscovered" resources. A quantitative resource assessment of the WLCI area is beyond the scope of this study. Previous resource estimates were published as part of the National Uranium Resource Evaluation (NURE) in the early 1980s (U.S. Department of Energy, 1980; Dribus and Nanna, 1982; Morris and Stanley, 1982).

In 1979, there were 17 operating uranium mines statewide and about 25 planned for development (Wyoming State Geological Survey, 2012c). Prices and demand for uranium dropped sharply in response to the Three Mile Island incident in Pennsylvania in 1979 (Anderson and Van Pelt, 2015) and again in 1986, probably in response to the Chernobyl disaster in Ukraine (in the former Soviet Union). From 1991 until May of 2012, when the Willow Creek property in the Powder River Basin began operations (Uranium One, 2012), all uranium production in the state has been from the Smith Ranch-Highland ISR in the Powder River Basin (Gregory, 2015), more than 50 kilometers $(\mathrm{km}), 30$ miles $(\mathrm{mi})$ northeast of the WLCI study area. There were no recently productive mines in the study area until Lost Creek ISR came online in August of 2013 (Ur-Energy, 2013).

Renewed demand for uranium in the last few years increased the price and caused a boom in exploration and development in several areas in and immediately adjacent to the WLCI study area. Uranium mineralized areas (plate 1) at Ketchum Buttes, Poison Basin, Shirley Basin, and Great Divide Basin are nearly all within WLCI, and the southern end of the Crooks GapGreen Mountain mineralized area in the northeasternmost part of the Great Divide Basin overlaps the northern margin of WLCI. Uranium deposits in Powder River Basin (including Pumpkin Buttes) and Wind River Basin (including Gas Hills and Copper Mountain), many of which are quite large, are not in the study area.

Outlines of the mineralized areas shown on plate 1 should be considered "fuzzy." They have been modified from Gregory and others (2010) (and precursors to that map, such as Harris, 1985), and are based on the presence of either contiguous claim blocks, continuous mineralization adjacent to prospective uranium properties, or suggestions of mineralization based on site entries in the U.S. Geological Survey's Mineral Resources Data System (MRDS) (U.S. Geological Survey, 2013), or extension of geologic host units or structures. Mineralized areas are not exactly the same as mining districts: the latter have defined administrative boundaries.

\section{Geology}

Several different uranium deposit types are present in Wyoming. Most of the state's productive uranium deposits are in Paleocene and Eocene sandstones in Tertiary basins. These include roll-front type deposits and tabular sandstone-hosted deposits. Together they make up the vast majority of the state's uranium resource. Other deposit types present in Wyoming include 
Tertiary unconformity-related deposits and paleokarst carbonate deposits in Mississippian rocks. There are also subeconomic occurrences of uranium in schroeckingerite and in coal. Only the first two types will be discussed here.

In the WLCI study area, most of the uranium deposits are roll-front types in Eocene (56-34 million years ago (Ma)) (U.S. Geological Survey, 2010) sedimentary rocks. These rollfront type uranium deposits were formed when groundwater migrated through the porous and permeable sedimentary rocks (sandstone and conglomerate). The groundwater leached the uranium from a source rock in an oxygenated environment (possibly from Precambrian igneous or metamorphic basement rocks, or from Paleozoic or Cenozoic volcanic ash-fall deposits (Wyoming State Geological Survey, 2012d)) and redeposited it in a reducing environment (Wyoming State Geological Survey, 2012e). All the uranium areas in WLCI except Poison Basin and Ketchum Buttes are roll-front types in Eocene (56-34 Ma) sedimentary rocks (U.S. Geological Survey, 2010).

Tabular sandstone-hosted uranium deposits are also recognized within the study area. Host rocks for these deposits are the Miocene North Park Formation in Ketchum Buttes (Gregory and others, 2010), Miocene Browns Park Formation in Poison Basin (Gregory and others, 2010), Eocene Wind River Formation in Shirley Basin (Gregory and others, 2010), and the interfingering Eocene Wasatch and Battle Spring Formations in the Crooks Gap-Green Mountain area (Dahlkamp, 2010). Battle Spring Formation is temporally equivalent to the Wind River Formation (Boberg, 2010, p. 658). North Park Formation is considered to be equivalent to the upper part of the Browns Park Formation (Gregory and others, 2010).

\section{Mining Methods}

Conventional open-pit and underground mining methods were employed in the study area until the early 1990s. Large volumes of rock and soil containing uranium ore were mined, crushed, and then processed at mills to extract the uranium by solution and concentrate it into yellowcake (Wyoming Mining Association, 2012).

Since the early 1990s, all uranium mining has been by in-situ recovery (ISR, also called insitu leach). In an ISR operation, oxygenated water (usually with some additives) is pumped underground to dissolve the uranium and that solution is pumped back up to a plant on the surface. The solution is passed through columns or tanks loaded with ion-exchange resin. The uranium is chemically extracted from the resin and concentrated. The rest of the process uses the same methods as for conventional recovery of yellowcake (Wyoming Mining Association, 2012).

\section{Development of Uranium Resources}

Brief visits to each of the uranium areas (plate 1) in WLCI between 2008 and 2010 confirm that most of the sites included in MRDS (U.S. Geological Survey, 2013) have been inactive for decades and that the vast majority of the sites included in the database never produced ore. At Ketchum Buttes, there was no evidence of extensive land disturbance, past or present, other than a long-abandoned site on the western summit of the buttes. Several small abandoned mine sites and tailings piles were evident in the Poison Basin area (fig. 2). Surface activity in Shirly Basin and Crooks Gap-Green Mountain areas since the early 1970s has been mostly limited to reclamation of past mining (Harshman, 1972) although apparently companies are still keeping claims active (fig. $3 H$ ). 


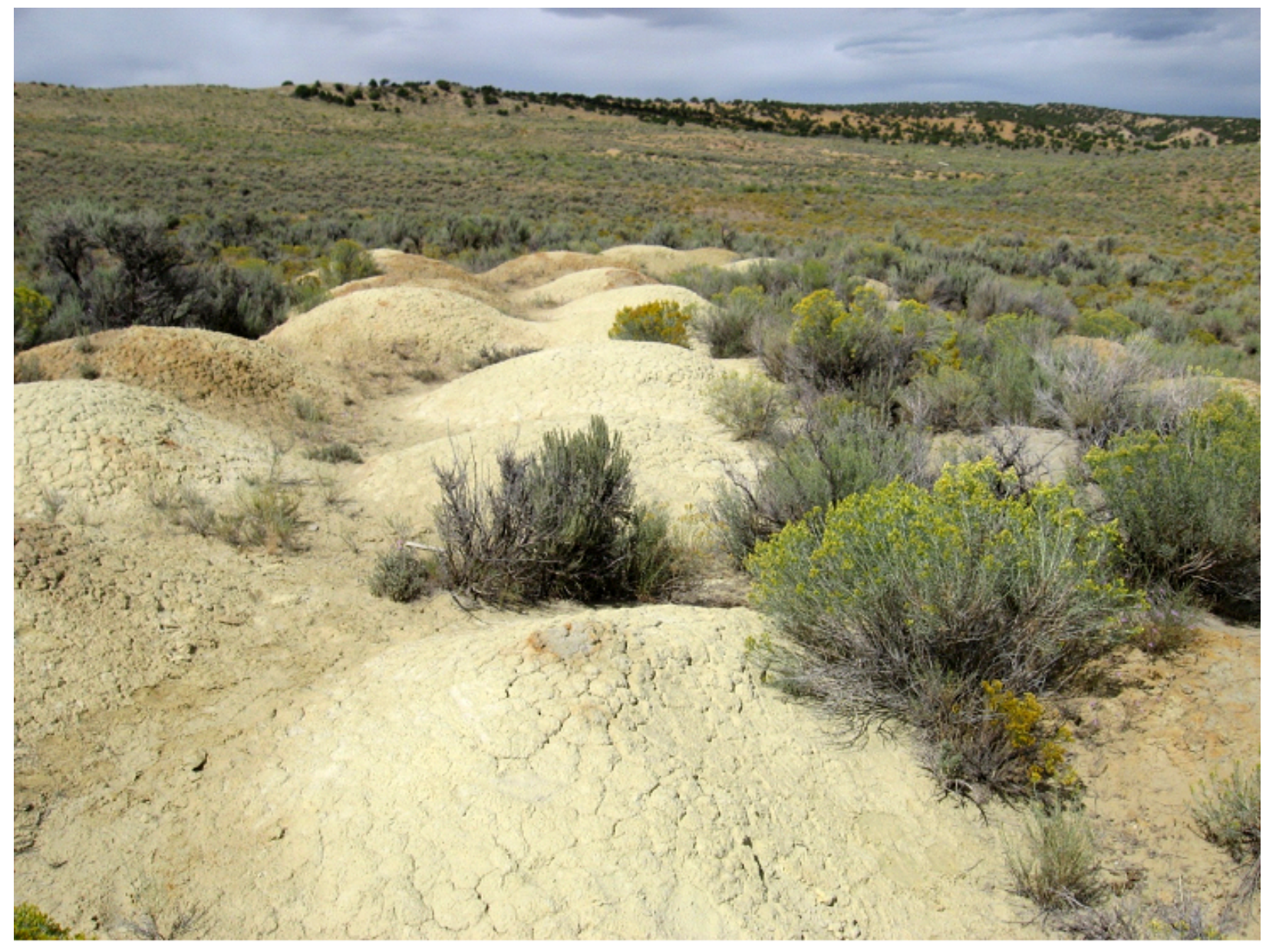

Figure 2. Decades-old waste piles left by uranium mining in Poison Basin, southwestern Wyoming, 2008. 


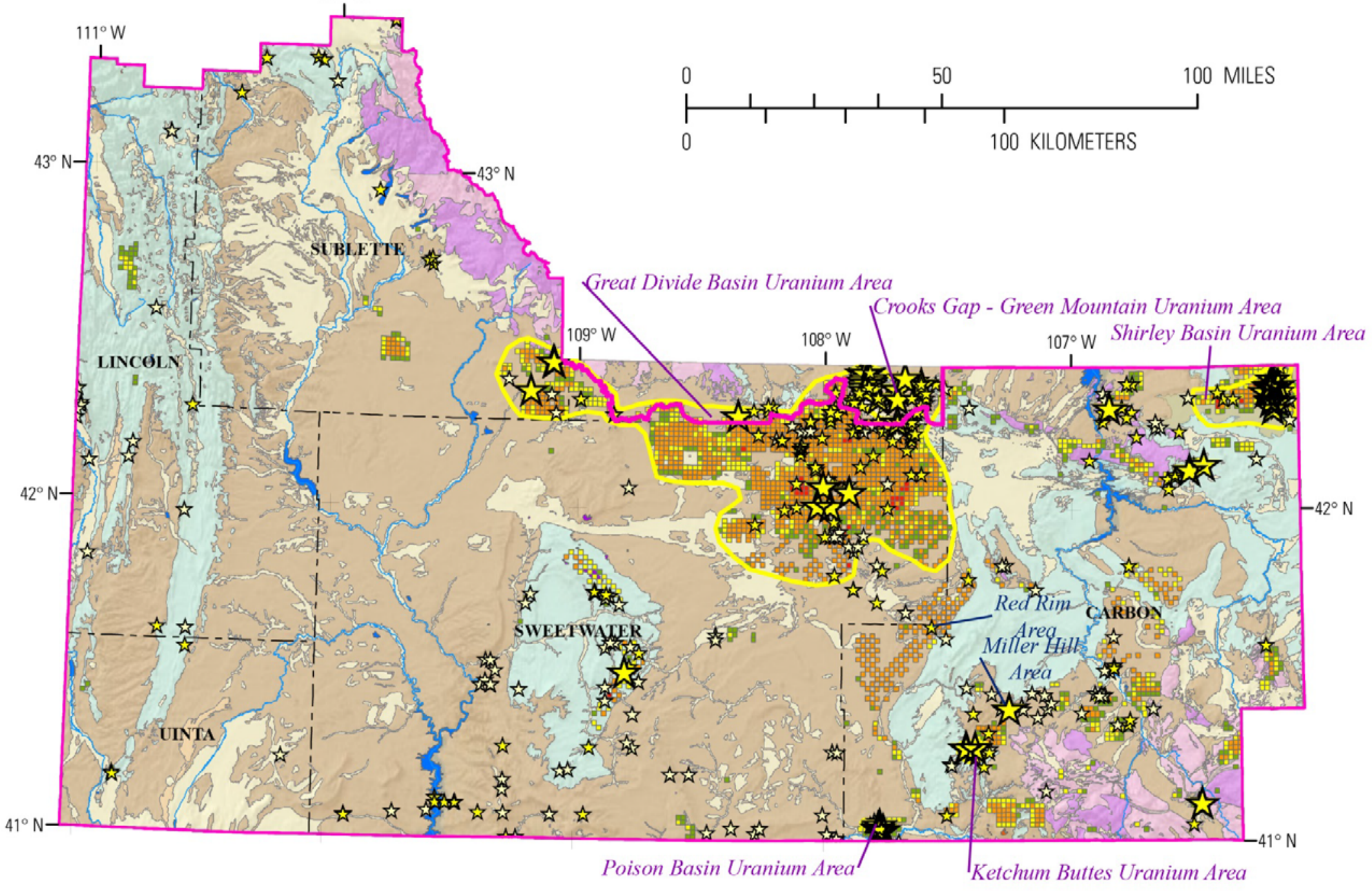




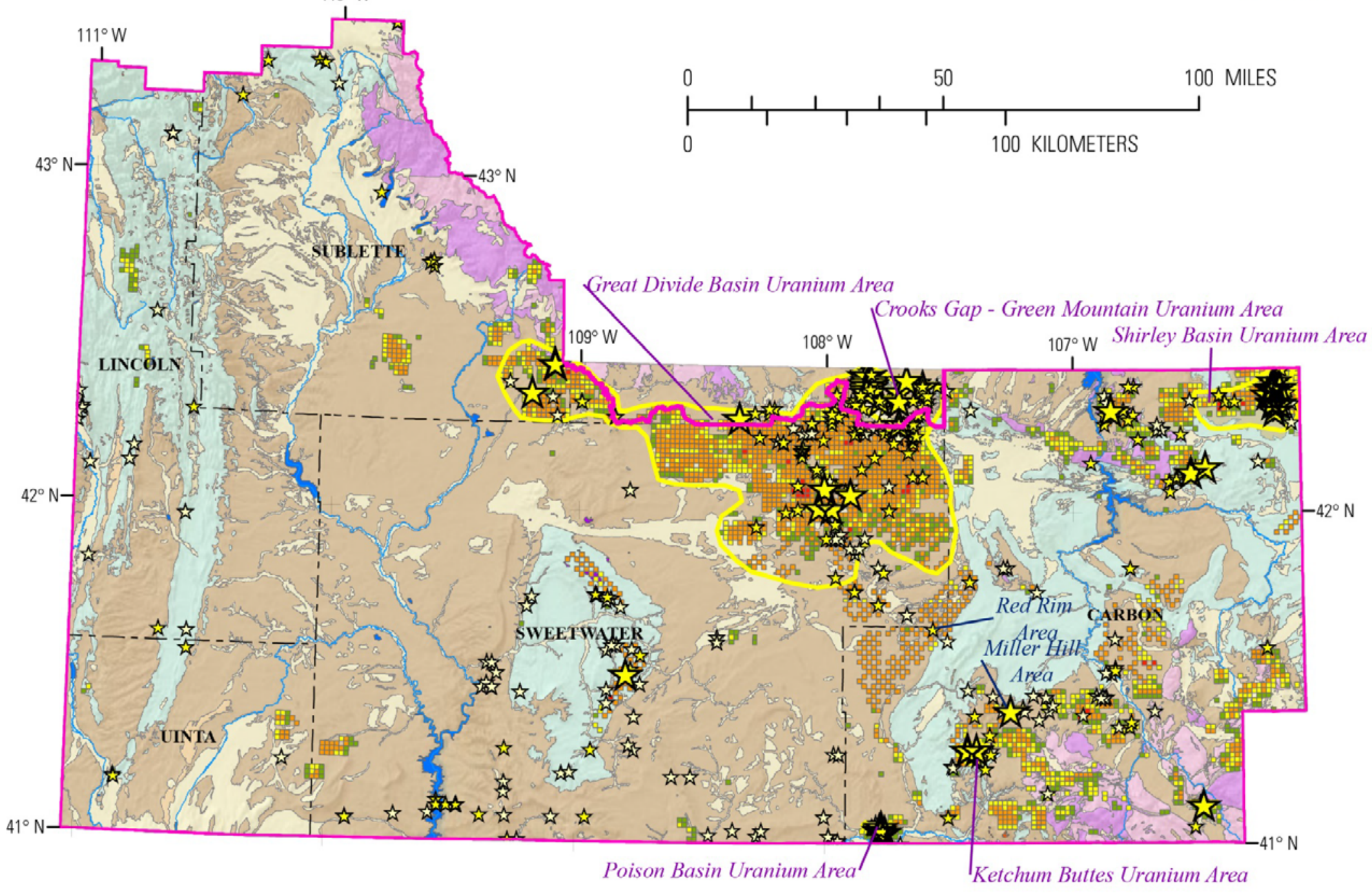




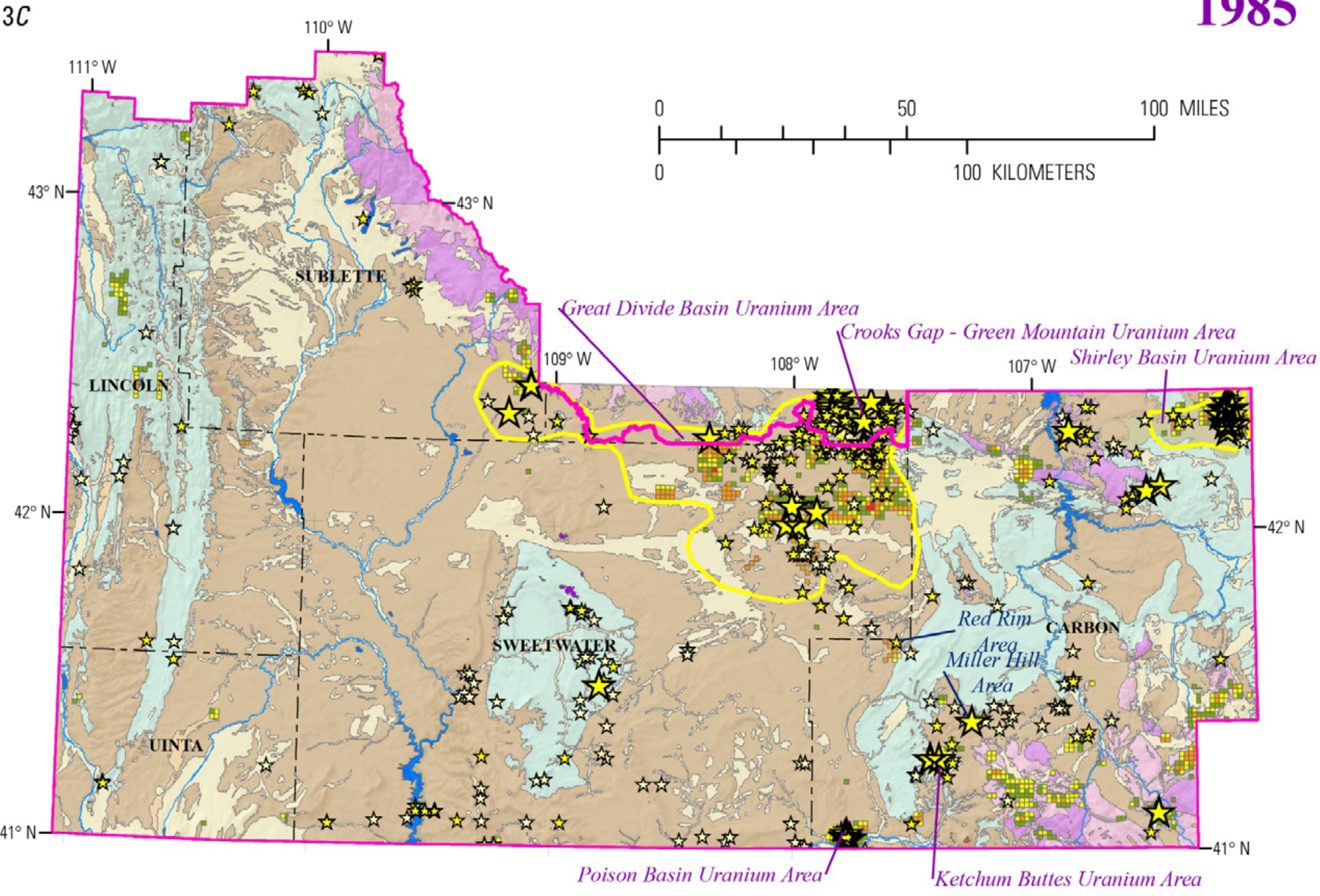




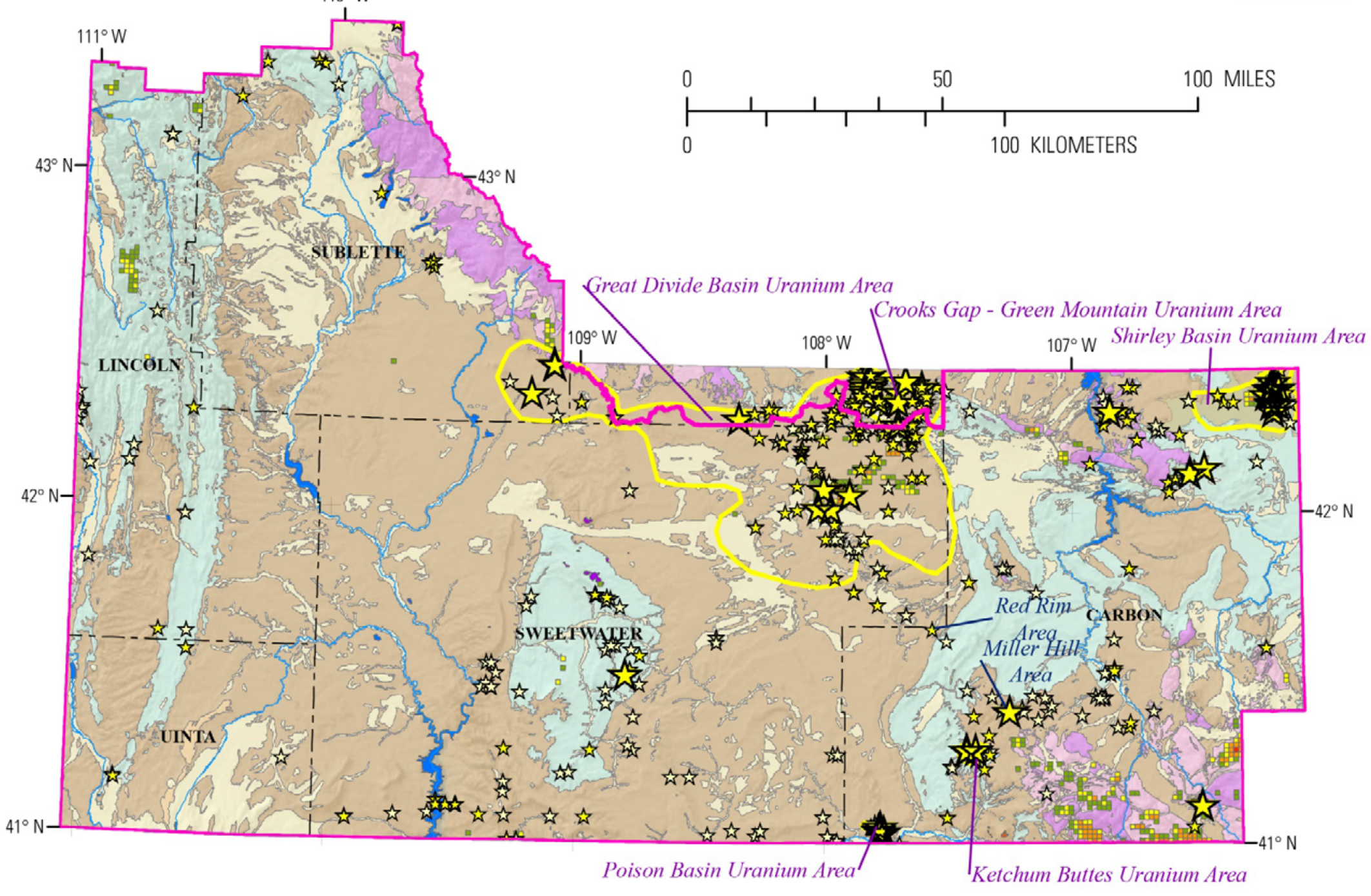




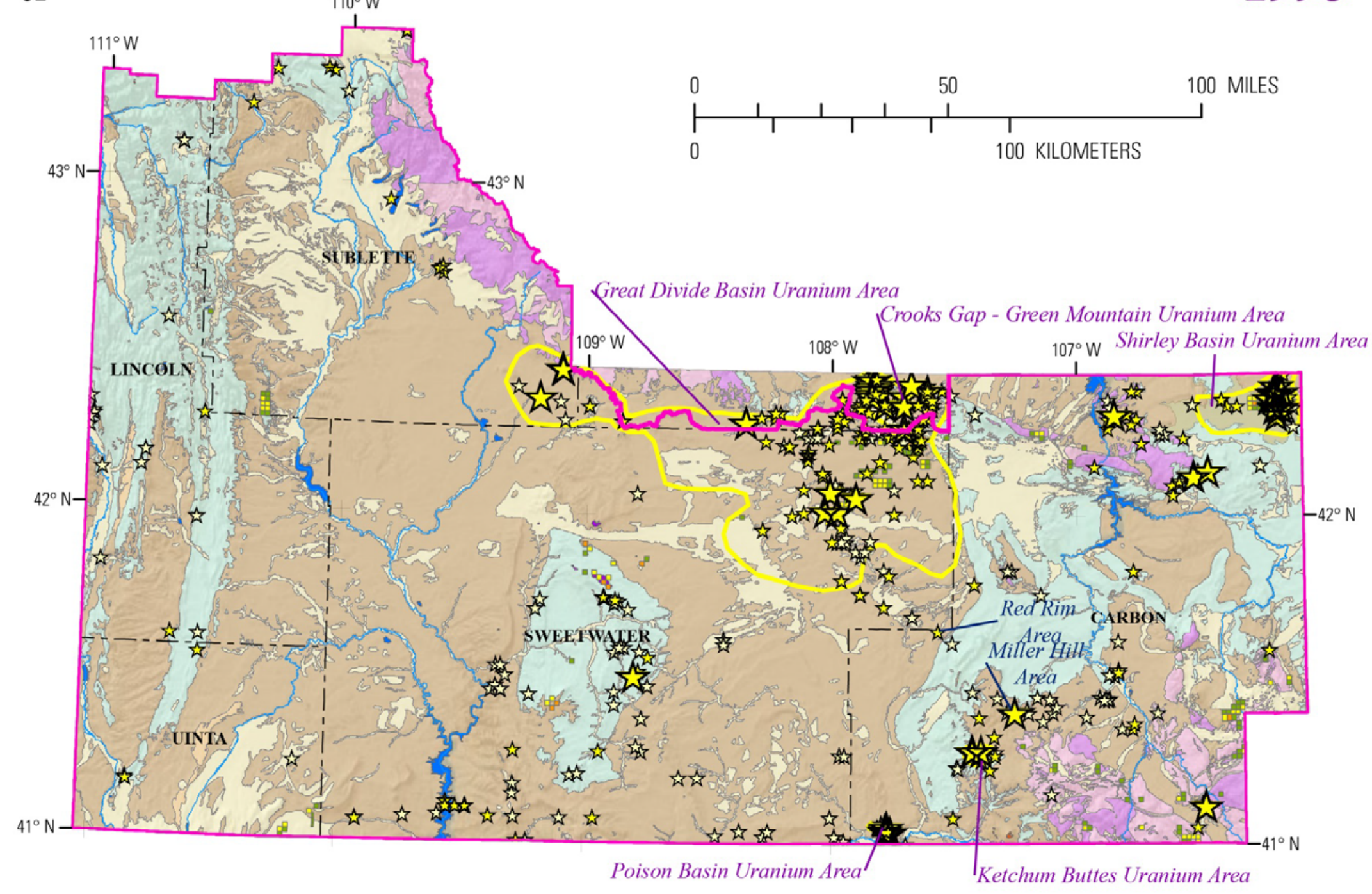




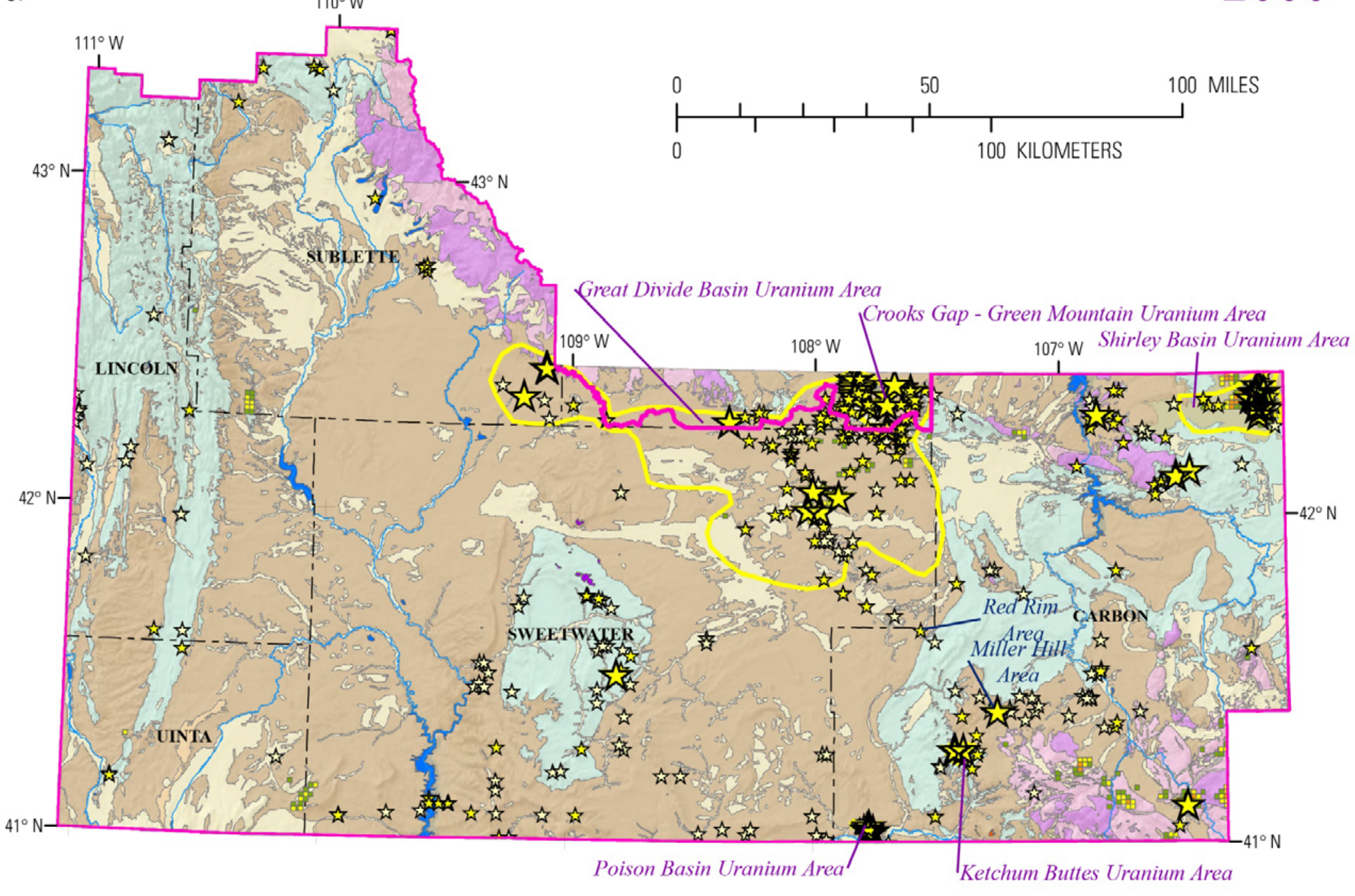




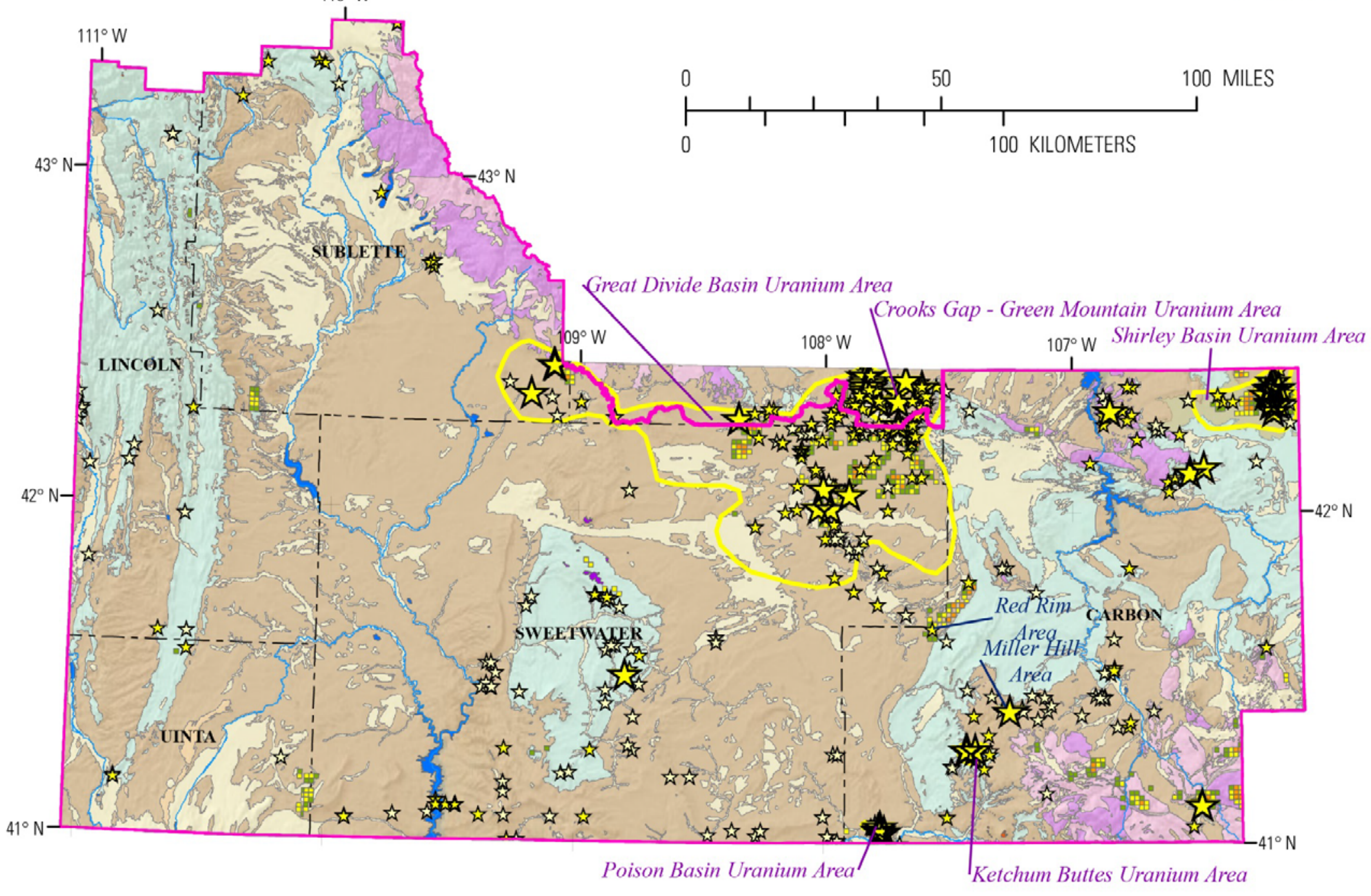




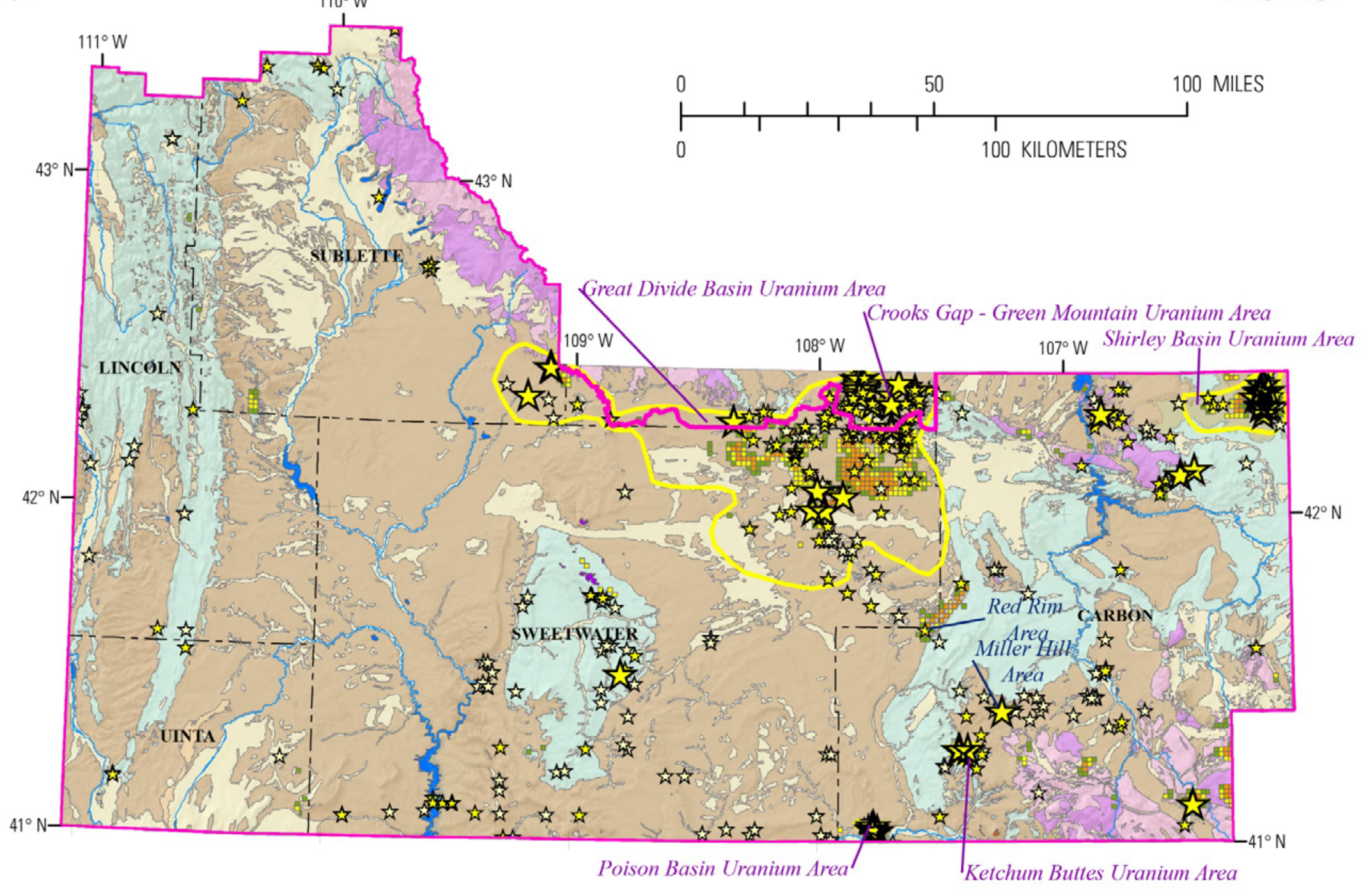




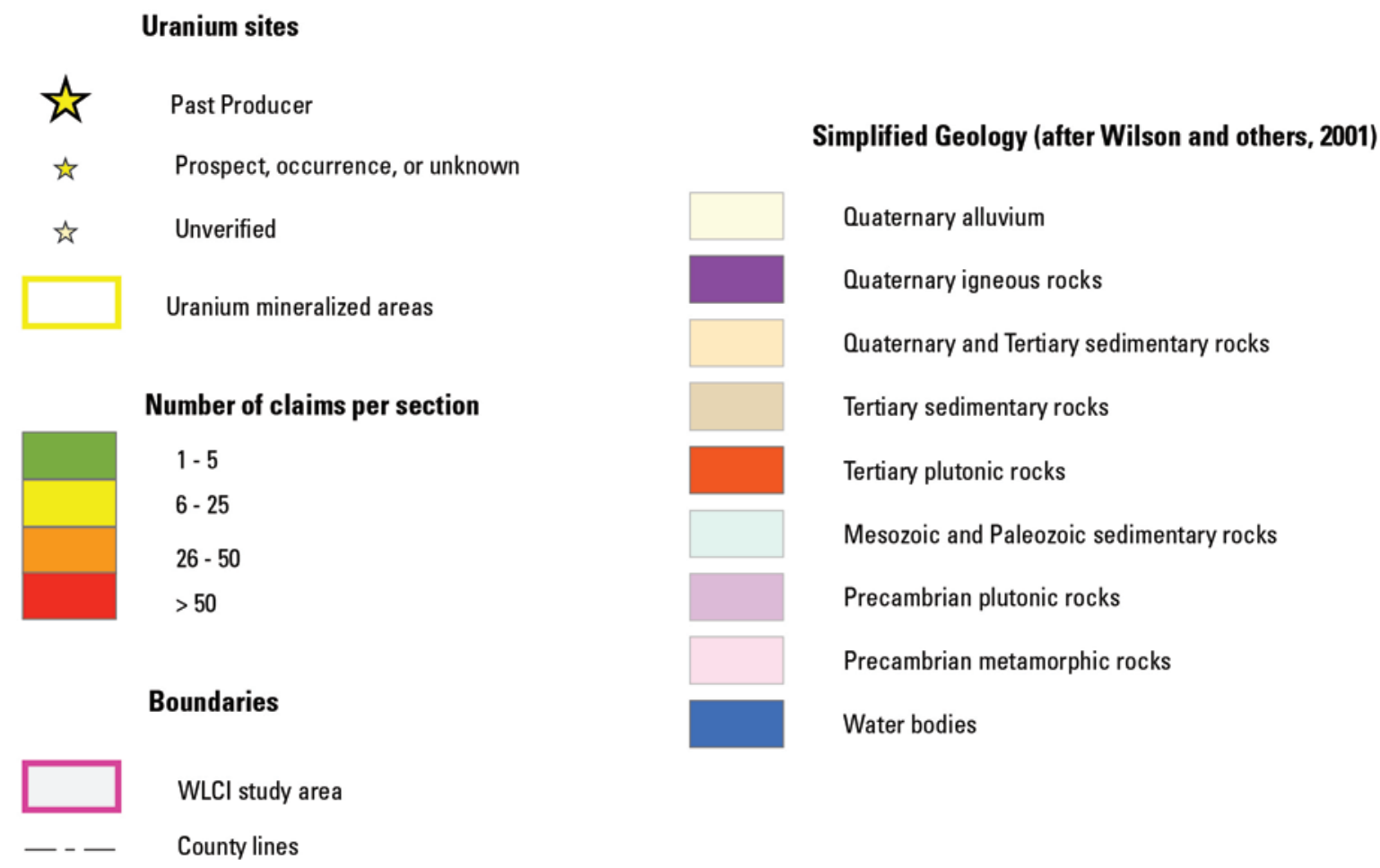

Figure 3. Claim activity, 1976-2010. Five-year-interval time slices ( $3 A, B, C, D, E, F, G, H)$ show number of lode claims per section. Lode claims include any locatable mineral, but it is assumed that most claims in and near the uranium mineralized areas or other uranium deposits are for uranium. Data from Causey, 2007 (revised 2011).

The Nuclear Regulatory Commission (NRC) has issued permits for uranium recovery sites at Lost Creek (using in-situ recovery) and the Sweetwater Mill (using conventional uranium mining) (U.S. Nuclear Regulatory Commission, 2012a). Additional information about the Lost Creek project can be found on the Bureau of Land Management (BLM) website (U.S. Department of the Interior Bureau of Land Management, 2012a).

Reviews of the JAB and Antelope projects in the northeastern part of Great Divide Basin submitted in 2008 are deferred (U.S. Nuclear Regulatory Commission, 2012b), as is the proposed project in Bison Basin (also known as West Alkali Creek) (U.S. Nuclear Regulatory Commission, 2012c). Permit requests for the Lost Soldier deposit, submitted to the NRC as a satellite to the Lost Creek project, was inactive as of 2012 (U.S. Nuclear Regulatory Commission, 2012d).

There is a proposed project (Juniper Ridge) in Poison Basin (WISE Uranium Project, 2012). A plan of operations (U.S. Department of the Interior Bureau of Land Management, 2012b) and notice inviting comment until June, 8, 2012 (U.S. Department of the Interior Bureau of Land Management, 2012c) are posted on the BLM website. 


\section{Mines, Prospects, and Occurrences}

The U.S. Geological Survey maintains a worldwide database, the Mineral Resources Data System (MRDS), of mineral districts, deposits, mines, prospects, and occurrences (U.S. Geological Survey, 2013). A subset of the data for Wyoming, along with supporting GIS data, was released in 2001 (Wilson and others, 2001). Compiled primarily from scientific and mining literature, the database is a repository for information about various deposits. In the course of the WLCI project, many of the records have been revised, new ones for missing properties have been added, and most of the unverifiable and duplicate records have been eliminated for the study area. Table 2 lists the verified producing and formerly producing mines and mineralized areas. Complete MRDS records are provided (in pdf format) for each of the 371 uranium entries within the boundaries of the WLCI and for the 110 verified records for productive sites in the adjacent Crooks Gap-Green Mountain area (appendix A) in Fremont County. These records augment the limited data in the ArcGIS files included in Biewick and Wilson (2014). The most useful field in the full MRDS record for a given mine is the reference field, which is not included in the ArcGIS files because it is not formatted in a compatible manner (see Biewick and Wilson, 2014). 
Table 2. MRDS records for Producers or Past Producers of uranium in the study area and the tonnage of ore (in metric tons) produced.

[Districts or areas listed first, followed by sites listed alphabetically. Complete records are included in appendix A]

\begin{tabular}{|c|c|c|c|c|c|c|c|c|c|c|c|c|c|c|c|}
\hline DEP_ID & SIG & NAME & COUNTY & QUAD250 & PRIMARY_CO & SECONDARY_ & TERTIARY_C & OPERATION_ & DEV_STATUS & WGS84_LAT & WGS84_LON & MAS_ID & MRDS_ID & REC_TP & tonnes ore \\
\hline 10205631 & $\mathrm{~N}$ & Miller Hill area & Carbon & Rawlins & Uranium - (U) & & & Unknown & Past Producer & 41.40416 & -107.256 & 560070654 & & Deposit & $>7.75$ \\
\hline 10400480 & $\mathrm{Y}$ & $\begin{array}{l}\text { Crooks Gap - } \\
\text { Green Mountain }\end{array}$ & Fremont & Casper & Uranium - (U) & & & Surface-Underground & Past Producer & 42.38995 & -107.83 & & & District & $4,389,811$ \\
\hline 10400478 & $\mathrm{~N}$ & $\begin{array}{l}\text { Ketchum Buttes } \\
\text { Uranium District }\end{array}$ & Carbon & Rawlins & Uranium - (U) & & & Unknown & Past Producer & 41.27506 & -107.396 & & & District & 1,870 \\
\hline 10400477 & $\mathrm{~N}$ & $\begin{array}{l}\text { Poison Basin } \\
\text { District }\end{array}$ & Carbon & Rawlins & Uranium - (U) & Vanadium - (V) & & Unknown & Past Producer & 41.04816 & -107.793 & & & District & 113,277 \\
\hline 10400479 & $\mathrm{Y}$ & $\begin{array}{l}\text { Shirley Basin } \\
\text { Uranium Area }\end{array}$ & Carbon & Casper & Uranium - (U) & & & Unknown & Past Producer & 42.33436 & -106.238 & & & District & $18,080,489$ \\
\hline 10400646 & $\mathrm{Y}$ & $\begin{array}{l}\text { Great Divide } \\
\text { Basin Uranium }\end{array}$ & Sweetwater & Lander & Uranium - (U) & & & Unknown & Producer & 42.088 & -108.088 & & & District & $2,805,198$ \\
\hline 10096609 & $\mathrm{~N}$ & Ajo Claims & Carbon & Casper & Uranium - (U) & & & Surface-Underground & Past Producer & 42.13607 & -106.466 & 560070180 & W032735 & Site & 3.6 \\
\hline 10181917 & $\mathrm{~N}$ & Bald Knob & Carbon & Casper & Uranium - (U) & & & Unknown & Past Producer & 42.12106 & -106.522 & 560070130 & & Site & 250 \\
\hline 10157558 & $\mathrm{Y}$ & $\begin{array}{l}\text { Bison Basin } \\
\text { Project }\end{array}$ & Fremont & Lander & Uranium - (U) & & & Unknown & Past Producer & 42.28459 & -108.353 & 560370466 & DE00263 & Site & 62,051 \\
\hline 10230279 & $\mathrm{~N}$ & Cedar Hills 1-12 & Carbon & Rawlins & Uranium - (U) & & & Unknown & Past Producer & 41.05416 & -107.774 & 560070140 & & Site & 18,930 \\
\hline 10157440 & $\mathrm{~N}$ & $\begin{array}{l}\text { Del Oro \#2 } \\
\text { Claim }\end{array}$ & Carbon & Rawlins & Uranium - (U) & & & Surface & Past Producer & 41.28636 & -107.431 & 560070153 & & Site & $?$ \\
\hline 10279171 & $\mathrm{~N}$ & $\begin{array}{l}\text { Jack Rabbit } \\
\text { Group }\end{array}$ & Carbon & Rawlins & Uranium - (U) & & & Surface & Past Producer & 41.04436 & -107.781 & 560070169 & & Site & 42,638 \\
\hline 10157087 & $\mathrm{~N}$ & Jenkins Project & Carbon & Casper & Uranium - (U) & & & Surface & Past Producer & 42.39166 & -106.181 & 560070099 & & Site & 479,522 \\
\hline 10133430 & $\mathrm{~N}$ & Juel Creek & Sublette & Lander & Uranium - (U) & & & Surface & Past Producer & 42.35774 & -109.189 & 560350040 & & Site & $?$ \\
\hline 10081134 & $\mathrm{~N}$ & Ketchum Butte & Carbon & Rawlins & Uranium - (U) & & & Unknown & Past Producer & 41.286 & -107.427 & 560070641 & W032860 & Site & 130 \\
\hline 10096604 & $\mathrm{~N}$ & Little Man Mine & Carbon & Casper & Uranium - (U) & & $\begin{array}{l}\text { Molybdenum - } \\
\text { (MO),Copper - } \\
\text { (CU),Graphite - } \\
\text { (GRF) }\end{array}$ & Unknown & Past Producer & 42.309 & -106.846 & & W032720 & Site & $\begin{array}{l}\text { "a small } \\
\text { shipment" }\end{array}$ \\
\hline 10091590 & $\mathrm{~N}$ & Lone Wolf & Sweetwater & Lander & Uranium - (U) & & & Unknown & Past Producer & 42.074 & -108.008 & & DC07330 & Site & 21 \\
\hline 10018872 & $\mathrm{~N}$ & Lucky Turk & Sweetwater & $\begin{array}{l}\text { Rock } \\
\text { Springs }\end{array}$ & Uranium - (U) & & & Unknown & Past Producer & 41.50884 & -108.802 & 560370062 & DC07304 & Site & 5.4 \\
\hline 10181711 & $\mathrm{~N}$ & Nall Lease & Carbon & Casper & Uranium - (U) & & & Surface & Past Producer & 42.37409 & -106.157 & 560070176 & & Site & 4,445 \\
\hline 10230604 & $\mathrm{~N}$ & $\begin{array}{l}\text { North Walker } \\
\text { Mine }\end{array}$ & Carbon & Casper & Uranium - (U) & & & Underground & Past Producer & 42.3264 & -106.161 & 560070079 & & Site & 671,423 \\
\hline
\end{tabular}


Table 2. MRDS records for Producers or Past Producers in the study area and the tonnage of ore (in metric tons) produced.—Continued [Districts or areas listed first, followed by sites listed alphabetically. Complete records are included in appendix A]

\begin{tabular}{|c|c|c|c|c|c|c|c|c|c|c|c|c|c|c|c|}
\hline DEP_ID & SIG & NAME & COUNTY & QUAD250 & PRIMARY_CO & SECONDARY_ & TERTIARY_C & OPERATION_ & DEV_STATUS & WGS84_LAT & WGS84_LON & MAS_ID & MRDS_ID & REC_TP & tonnes ore \\
\hline 10206596 & $\mathrm{~N}$ & Pard & Sublette & Lander & Uranium - (U) & & & Unknown & Past Producer & 42.35744 & -109.073 & 560350023 & & Site & 386 \\
\hline 10080431 & $\mathrm{~N}$ & $\begin{array}{l}\text { Petrotomics } \\
\text { Mine }\end{array}$ & Carbon & Casper & Uranium - (U) & & & Surface & Past Producer & 42.33026 & -106.186 & 560070187 & W031621 & Site & $8,502,326$ \\
\hline 10107762 & $\mathrm{~N}$ & Platt Mine & Carbon & Rawlins & $\begin{array}{l}\text { Niobium } \\
\text { (Columbium) - }\end{array}$ & & & Surface-Underground & Past Producer & 41.1183 & -106.487 & 560070203 & D001896 & Site & 12 \\
\hline 10018832 & $\mathrm{~N}$ & $\begin{array}{l}\text { Poison Basin } \\
\text { Claim Group }\end{array}$ & Carbon & Rawlins & Uranium - (U) & & & Surface & Past Producer & 41.03952 & -107.76 & & DC06966 & Site & 55,338 \\
\hline 10281407 & $\mathrm{~N}$ & $\begin{array}{l}\text { Prospect } \\
\text { Mountains }\end{array}$ & Sublette & Lander & Uranium - (U) & & & Surface & Past Producer & 42.44134 & -109.104 & 560350041 & & Site & ? \\
\hline 10132282 & $\mathrm{~N}$ & $\begin{array}{l}\text { Shirley Basin } \\
\text { Mine }\end{array}$ & Carbon & Casper & Uranium - (U) & & & Surface-Underground & Past Producer & 42.371 & -106.194 & 560070082 & W032895 & Site & \\
\hline 10278730 & $\mathrm{~N}$ & $\begin{array}{l}\text { South Walker- } \\
\text { Sullivan }\end{array}$ & Carbon & Casper & Uranium - (U) & & & Surface & Past Producer & 42.30436 & -106.181 & 560070080 & & Site & 239,497 \\
\hline 10133291 & $\mathrm{~N}$ & State School \#1 & Sweetwater & Casper & Uranium - (U) & & & Surface & Past Producer & 42.01423 & -107.978 & 560370495 & & Site & 203 \\
\hline 10205128 & $\mathrm{~N}$ & Sullivan Mine & Carbon & Casper & Uranium - (U) & & & Surface & Past Producer & 42.36686 & -106.188 & 560070105 & & Site & $?$ \\
\hline 10106208 & $\mathrm{Y}$ & $\begin{array}{l}\text { Sweetwater Mill } \\
\text { and Mine }\end{array}$ & Sweetwater & Casper & Uranium - (U) & & & Surface & Past Producer & 42.05717 & -107.903 & 560370523 & W031620 & Site & $2,482,166$ \\
\hline
\end{tabular}


The following are other caveats to consider when using the MRDS records:

1. No attempt has been made to ascertain if these sites are currently active or abandoned. However, presence of a record indicates that mineralization of some sort has been reported.

2. All locations are points. In some cases the database contains multiple locations for a single record (for instance, for some mines with multiple workings, or deposits developed by multiple mines). MRDS does not contain an outline of mineralized ground (whether that is a claim, claim block, lease, deposit, or district).

3. The term "mine" has multiple meanings. Sometimes it applies to a single working (or even an undeveloped claim). Other times it refers to a company's property with many workings. In general, the users cannot use these coordinates to precisely locate the sites described by these records, but they will get to the general vicinity of the property.

4. Accuracy and precision of site locations differ for different deposit types. As most metal mines are fairly compact, the locations are closer than, say, for properties hosting uranium accumulations (especially ISR prospects) which target an areally extensive deposit not exposed at the surface.

5. More than half of the uranium records do not have a valid reference source. These are coded as Not-validated and are shown with small pale yellow stars on plate 1. Records of unknown or unnamed sites, even if they have a reference, are also coded this way. Records that have a valid reference are shown as darker yellow, with Producers as largest stars, Past Producers as medium stars, and Occurrences and Prospects small stars.

MRDS is an active and constantly changing database. The records presented herein are the contents as of January 2013. Capitalization is used as an indication of what data have been edited. Originally, MRDS data were in all caps. Several years ago, a computer script was run on a few selected fields to convert upper case to initial capitals. Since then, a former MRDS team member who edited a record may have corrected some insignificant words such as "And," "Or," "If" to "and," "or," "if." A record maintaining such apparent typos has not been revised. Similarly, References appearing in uppercase and lowercase have likely been revised-no attempt to autoconvert those to initial capitals was ever attempted. Revisions and new entries should be correctly displayed in uppercase and lowercase.

\section{Mineral Claim Activity 1976 to 2010}

Changes in mineral exploration through time can be seen in the mining claim data (fig. 3A-H). Mining claim activity on Federal land has been recorded with the BLM since it was required by the Federal Land Policy and Management Act of 1976 (Public Law 94-579), Sec. 314. The claim data for WLCI were excerpted from data for Wyoming that were compiled by Causey (2007, rev. 2011). Claimants do not have to name the commodity that is being sought, so one must assume that the vast majority of claims in the uranium areas are for uranium. Likewise, claims outside known uranium areas but within other known mineralized areas are more likely for commodities known to occur in those areas, such as gold (excluding placer gold), silver, lead, or copper. Claim data are valid only for public lands.

The number of open or valid lode claims are aggregated by Public Land Survey section (roughly 1 square mile) and plotted: green, only 1-5 claims per section; yellow, 6-25; orange 26-50; red, greater than (>)50 (fig. 3). The maximum claim size is 600 feet $(\mathrm{ft}) \times 1,500 \mathrm{ft}$ (claim sizes were mandated by the Mining Law of 1872); therefore, only 31 maximum-sized claims can 
fit in a section. Sections with more than 31 claims may have smaller or irregularly shaped claims or the claims were overstaked (overlapping) so as not to miss any potentially favorable ground due to surveying errors. The value of the claim data in this application is that it shows where there is the most exploration interest in any given year. Because the change in number of claims tends to be gradual from year to year, the series of maps (fig. 3A-H) is constructed in 5-year increments. (The data are for 1976 to 2010, therefore the first increment from 1976 to 1980 contains only 4 years.)

The extent of the claims and the "hot spots" varied during these 5-year increments. In the eastern part of Great Divide Basin there were many claims in 1976 (fig. $3 A$ ) but very few by 1980-1985 (fig. 3B, C) due to uranium's price decline. The slight rebound since 2005 (fig. $3 G$, $H$ ) was due to increased price for $\mathrm{U}_{3} \mathrm{O}_{8}$ and advances in ISR technology. Claim activity in the Shirley Basin area has been less volatile - interest was highest before 1985 (figs. $3 A-C$ ) but many claims have remained open to the present. In the Poison Basin and Ketchum Buttes areas, open claims fell off gradually to 1990 (figs. $3 A-D$ ) when there were no claims in either area. By 2000 (fig. $3 F$ ) there were several claims in the Poison Basin and increased numbers in 2005 and 2010 (fig. 3G, $H$ ). After a 20-year absence of claims, as of 2010 (fig. $3 H$ ) there were a few claims on the northern edge of Ketchum Buttes. The last interest in the Miller Hill uranium area (approximately 2 miles northeast of Ketchum Buttes) was in 1980 (fig. 3B). A northeast-trending block of claims at Red Rim, west of Rawlins, is a uranium prospect.

\section{Uranium Mineralized Areas}

\section{Ketchum Buttes}

Ketchum Buttes, last active in the 1970s(?) is virtually abandoned: only an old pit on the summit of the western butte is still visible. Deposits (or occurrences) in the Ketchum Buttes area are small (Ketchum Buttes, Cloudy Group, Del Oro, Friday, and Siwash Claims; see appendix A) and until recently there has been little interest in the area. Host rocks are mudstones and sandstones of the Tertiary North Park Formation (Vine and Prichard, 1959). These were sandstone-hosted roll-front type deposits containing uranophane assaying as high as 0.32 percent $\mathrm{U}_{3} \mathrm{O}_{8}$ (0.27 percent uranium equivalent) (MINOBRAS, 1976). The district produced 1,870 tonnes $(2,061$ short tons) of uranium ore (Gregory and others, 2010). The average grade of the ore is unknown, and so too is the amount of contained uranium. Ketchum Buttes was not included with the Wyoming basins that were evaluated by Dahlkamp (2010).

As of 2006, Strathmore Minerals Corporation owned the mineral rights to the Ketchum Buttes property. The exact location of the property (which includes 21 unpatented lode claims over the Foster ore body) is uncertain. Strathmore reported a near-surface uranium deposit with a planned conventional open-pit uranium mine. The deposit is hosted in sandstone and conglomerate of the Miocene Browns Park Formation. Historically demonstrated resources (not NI 43-101 compliant ${ }^{1}$ ) are $577 \mathrm{tU}\left(1,500,000\right.$ pounds $\mathrm{U}_{3} \mathrm{O}_{8}$ ) (Strathmore Minerals Corporation, 2006). Strathmore expected to develop this property as a conventional open pit, extracting the uranium through heap leach, or possibly processing it at the Sweetwater Mill (Strathmore Minerals Corporation, 2006). As of September 2009, there was no visible mineral development

\footnotetext{
${ }^{1}$ National Instrument 43-101 (NI 43-101) defines rules and guidelines for reporting and displaying information related to mineral properties owned by, or explored by, companies which report these results on stock exchanges within Canada in its Standards of Disclosure for Mineral Projects. The purpose is to ensure that misleading, erroneous or fraudulent information relating to mineral properties is not published and promoted to investors on the stock exchanges overseen by the Canadian Securities Authority.
} 
in the area. All of the exploratory drill holes have been plugged and the site has been recontoured. Late in 2012, Stathmore terminated its agreement and withdrew its plan of operations from the Bureau of Land Management (Mark Newman, U.S. Bureau of Land Management, oral commun., January 10, 2013).

\section{Poison Basin}

At Poison Basin, old waste piles (fig. 2) and trenches (fig. 4) appear to have been abandoned for decades. Total production from Poison Basin district was 113,254 tonnes $(124,867$ short tons) of uranium ore (Gregory and others, 2010). Both Crosshair Exploration Corporation (Beahm, 2012) ${ }^{2}$ and Strathmore Minerals Corporation (Strathmore Minerals Corporation, 2006, 2010) have shown recent interest in the Poison Basin area.

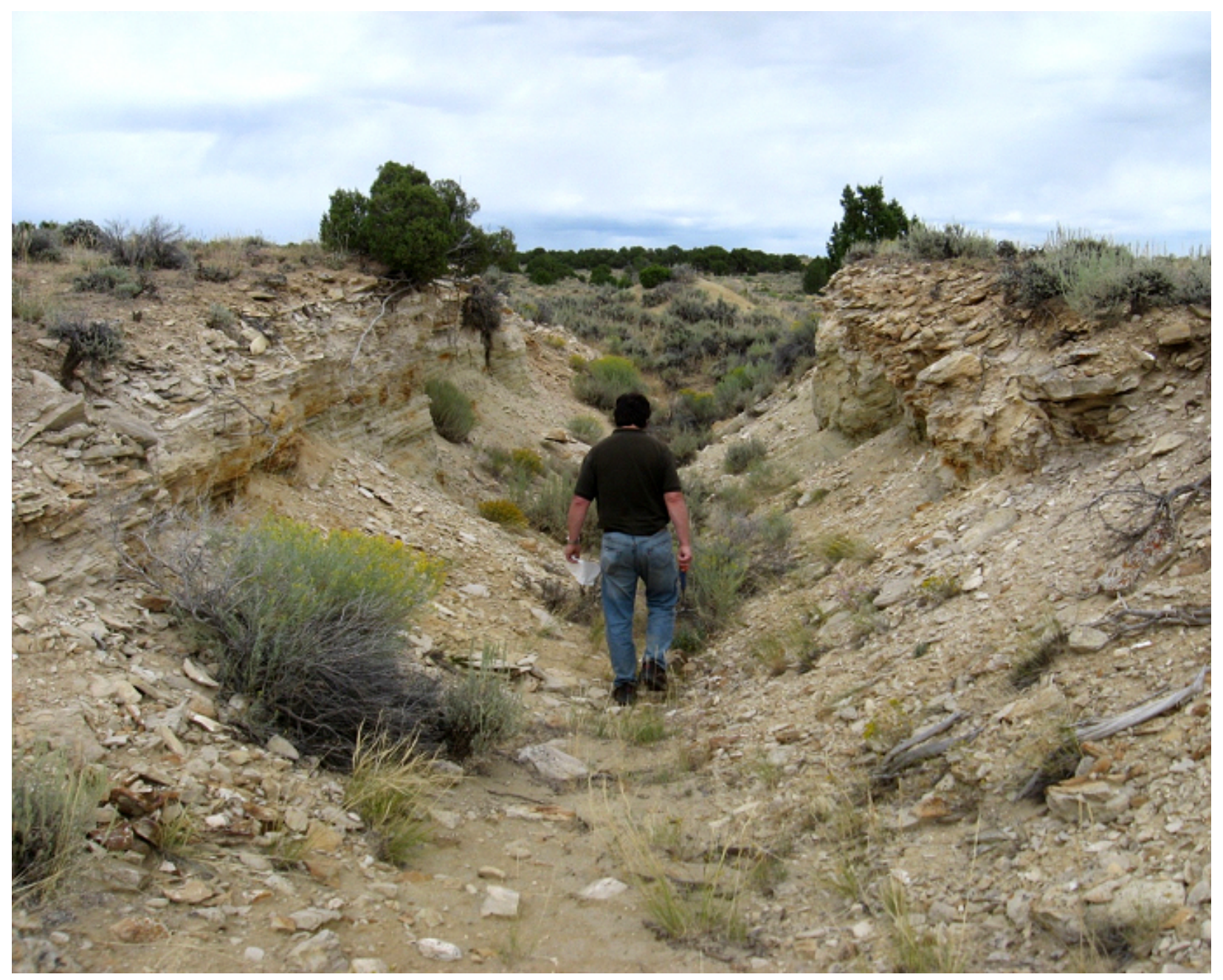

Figure 4. Abandoned trench in Poison Basin, southwestern Wyoming, 2008.

${ }^{2}$ Indicated Resources: 4,140,000 tonnes at 0.063 percent $=2,608$ tonnes $\mathrm{U}_{3} \mathrm{O}_{8}=2,211 \mathrm{tU}($ Beahm, 2012). 
Sandstone-type uranium deposits in this area were discovered in 1953 near the town of Baggs (population 440 as of 2010 Census) and mined from 1954 through 1981. Production came from eight properties and amounted to about $350 \mathrm{tU}$ in ore with grades averaging 0.17 percent uranium (Dahlkamp, 2010). Based on these numbers a production estimate of 205,882 tonnes ore can be calculated, which is almost twice the 113,254 tonnes (124,867 short tons) reported by Gregory and others $(2010)^{3}$. Most of the mining was from open pits, but there were also some underground workings (fig. 5).

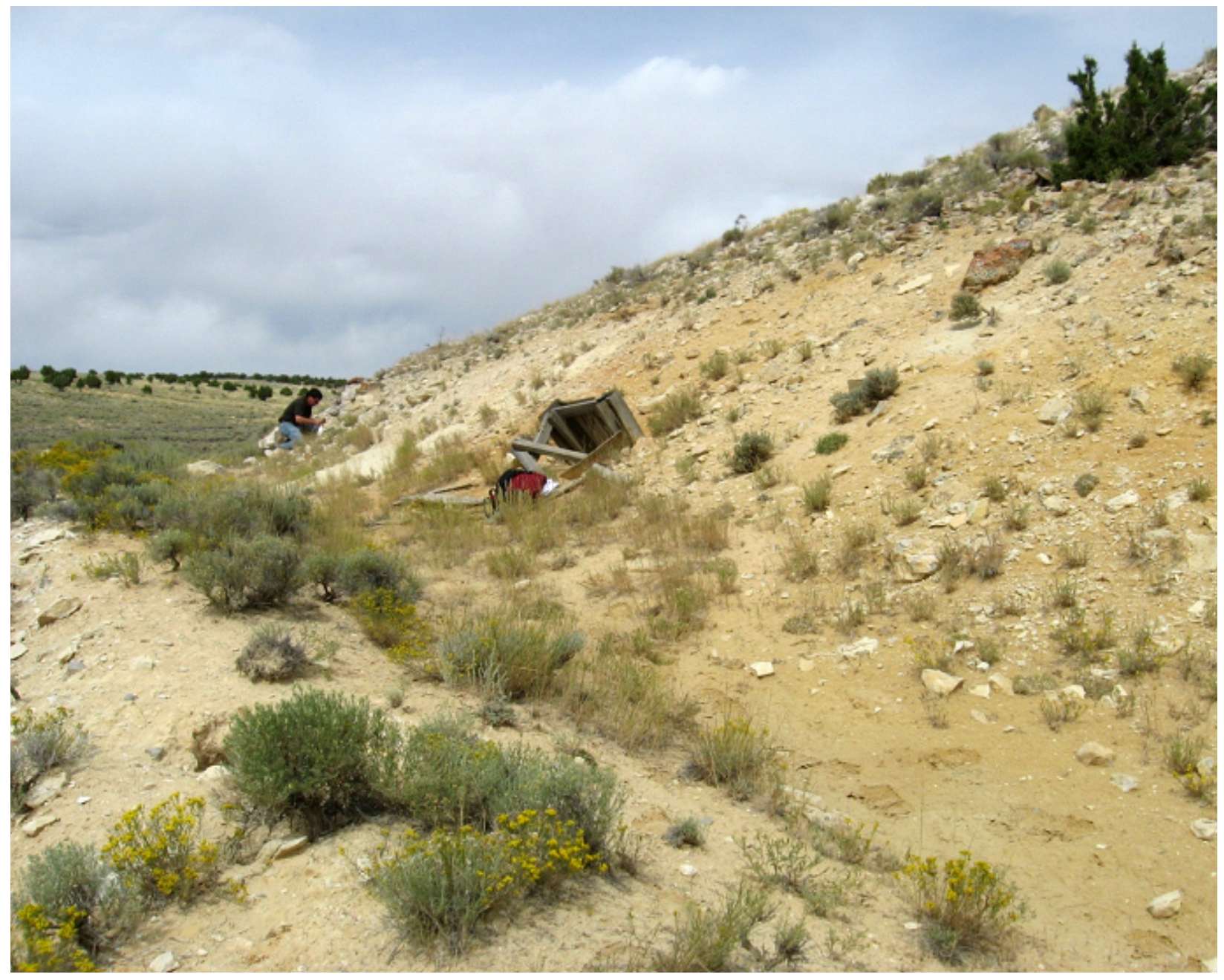

Figure 5. One of the small abandoned underground mines in Poison Basin, southwestern Wyoming, 2008.

The Poison Basin deposit (including Poison Basin, Teton, and Juniper Ridge properties) is hosted in unoxidized and oxidized sandstones of the top 20 meters $(\mathrm{m})$ of the 150-m-thick Miocene Browns Park Formation that forms a depositional syncline cut by normal faults (Dahlkamp, 2010, p. 206-207). The Poison Basin deposit extends approximately $20 \mathrm{~m}$ below the

${ }^{3}$ Gregory and others (2010) credits the district with production totaling 113,254 tonnes (124,867 short tons) of ore: Teton Group (1,000 short tons, estimate $=907$ tonnes), Cedar Hills (20,867 short tons $=18,926$ tonnes), Teton Group (estimated 1,000 short tons $=$ estimated 907 tonnes, but note that this is the same name and same tonnage and may be a duplicate record with alternate location), Poison Basin and Matt 3 (61,000 short tons $=55,327$ tonnes), and Jack Rabbit (47,000 short tons $=42,629$ tonnes). 
surface and consists of weakly mineralized (less than 0.1 percent) Browns Park Formation containing smaller, higher-grade ore bodies (averaging 0.17 percent uranium) with ore-grade mineralization approximately 1 to $3 \mathrm{~m}$ thick. Ore bodies are in a lenticular or blanket-like configuration and are essentially concordant with very gently dipping sediments. On the south side of the deposit, natural gas was encountered in drill holes in the Browns Park Formation (Dahlkamp, 2010, p. 207). At the Juniper Ridge ${ }^{4}$ property, resources of 3,000 tU at an average grade of 0.05 percent with a cutoff grade of 0.017 percent $U$ in three ore bodies at less than $80 \mathrm{~m}$ depth are estimated to be recoverable by open-pit mining (Dahlkamp, 2010). These data suggest an estimate of about 6,000,000 tonnes ore. About one third of this resource is oxidized ore (containing the uranium-bearing minerals autunite and brannerite) above the water table (Dahlkamp, 2010, p. 207). A more recent evaluation estimates the indicated resource at Juniper Ridge at 3,754,980 tonnes at an average grade of 0.063 percent $\mathrm{U}_{3} \mathrm{O}_{8}$ (by using a 0.1 percent cutoff containing 2,003 tU (Beahm, 2012)).

\section{Shirley Basin}

The Shirley Basin uranium area is in the northeast corner of Carbon County. Shirley Basin contained original resources of more than $47,000 \mathrm{tU}$ at grades ranging from $<0.07$ to 0.5 percent uranium (Dahlkamp, 2010, p. 176). This would compute to somewhere between $67,000,000$ to $9,400,000$ tonnes of ore. According to the values reported by Gregory and others (2010), the seven productive mines in the Shirley Basin uranium area produced a total of $18,080,489$ short tons $^{5}(16,399,003$ tonnes) of ore. There is no mention of the average ore grade; therefore, total contained uranium cannot be directly compared with Dahlkamp's estimate.

Shirley Basin, an intermontane Tertiary basin with continental fill, is one of the smallest basins in Wyoming to contain roll-front type deposits. Uranium deposits occur in the Eocene Wind River Formation in the central part of the basin. The Wind River Formation overlies Precambrian to Cretaceous rocks, and it is overlain by tuffaceous silt and mudstones of the Oligocene White River Formation. The youngest pitchblende ore in the Shirley Basin is about $24 \pm 3 \mathrm{Ma}$, the oldest ore sample formed before $35 \mathrm{Ma}$ (Dahlkamp, 2010, p. 162).

Ludwig (1978) subdivided uranium ore in the Shirley Basin into three types: (a) disseminated pitchblende ore, (b) calcite-cemented ore, and (c) massive pitchblende ore. Uranium content varies from 12 percent in calcite-cemented ore, 1-2 percent in disseminated pitchblende ore, and 65-72 percent in massive pitchblende ore (Ludwig, 1978, p. 34). These categories apply to most deposits in the Wyoming Basins (Dahlkamp, 2010, p. 154).

The Shirley Basin ore bodies are not extensive in lateral dimension or tonnage. Individual mined ore bodies had resources between a few hundred and several thousand tonnes of uranium. These ore bodies rarely persisted in length along the redox front for more than $750 \mathrm{~m}$, and in width for several tens of meters to as much as $100 \mathrm{~m}$. Thicknesses (vertical to the rolls) were commonly a few meters, and occasionally up to $10 \mathrm{~m}$. Trailing ends ranged from a few centimeters to several tenths of a centimeter in thickness. In-situ ore grades ranged from a few hundredths to 20 percent uranium (Dahlkamp, 2010, p. 179).

\footnotetext{
${ }^{4}$ Urangesselschaft USA estimated the deposit contained 8 to 15 million pounds of U3O8 (4,000 to 7,500 [short] tons) and planned to build a mine with a 2,000 ton per day capacity (ENSR Corporation and Booz Allen \& Hamilton, 2003, p. 3-57)

${ }^{5}$ Productive mines included (values reported by Gregory and others, 2010, are in tons of ore, not contained $\mathrm{U}_{\text {or }} \mathrm{U}_{3} \mathrm{O}_{8}$ ): Pathfinder-Shirley Basin $(7,170,586$ short tons $=6,503,721$ tonnes), Night Owl ( 93 short tons $=84$ tonnes, small relative to the others in the area, but this mine is just east of the district), Uranium Supply-Jenkins (528,582 short tons $=479,424$ tonnes), North Walker (740,117 short tons $=671,286$ tonnes), South Walker $(264,000$ short tons $=239,448$ tonnes $)$, Getty Oil-Petrotomics $(9,372,211$ short tons $=8,500,595$ tonnes $)$, Nall $(4,900$ short tons $=4,444$ tonnes).
} 
There is current claim activity (fig. $3 H$ ) in Shirley Basin. Projects are underway by Crosshair Exploration and Cameco (Mark Newman, U.S. Bureau of Land Management, oral commun., Jan. 10, 2013) ${ }^{6}$. The major sites that are accessible have been fully reclaimed (fig. $6 A, B$ ) or repurposed (fig. $7 A, B$ ).
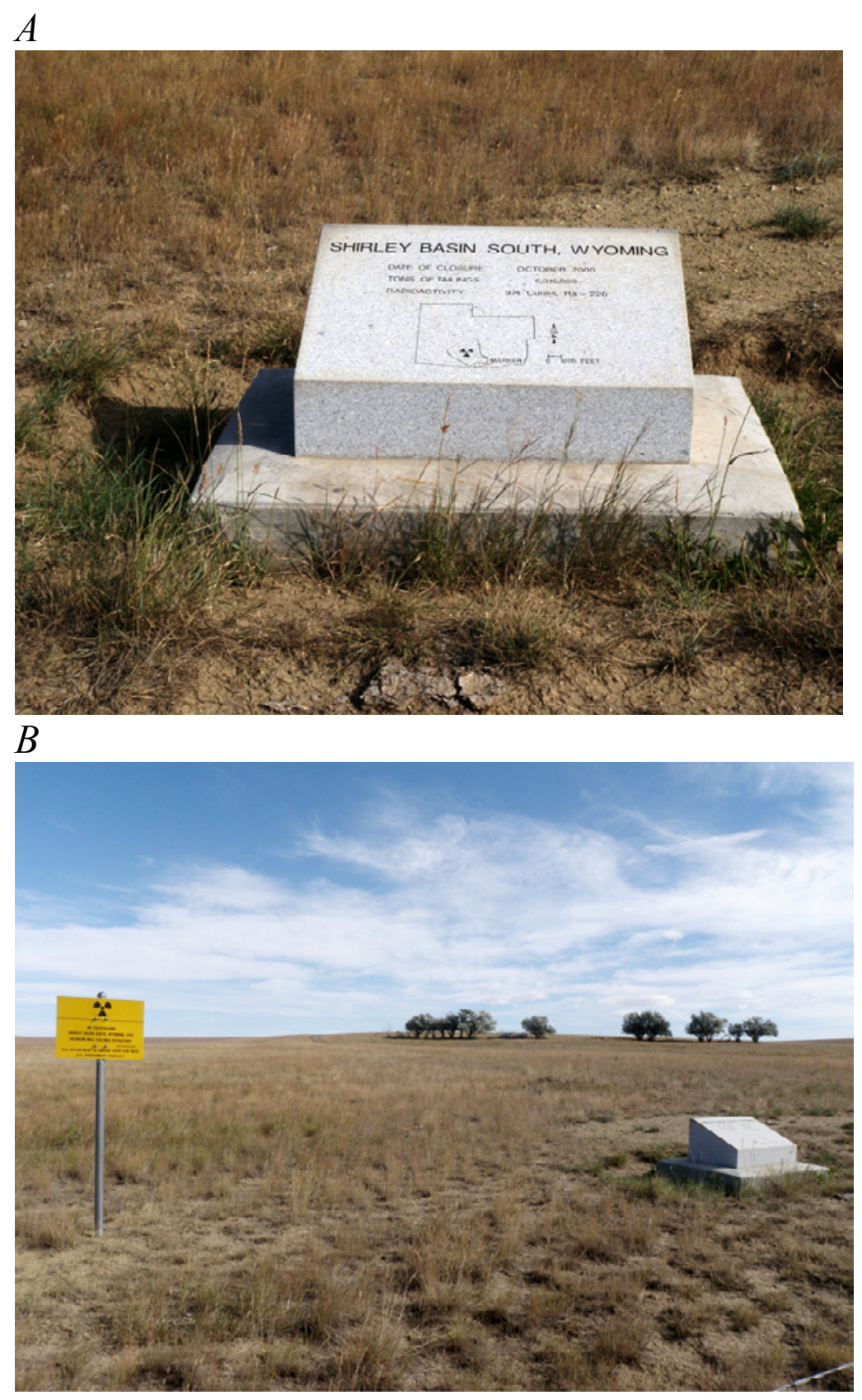

Figure 6. Shirley Basin, a reclaimed mine site, 2009. A, Monument. B, Surroundings to horizon.

\footnotetext{
${ }^{6}$ According to WISE-Uranium Project (http://www.wise-uranium.org/upusawy.html\#PMCSHIRLEYB), "On Aug. 30, 2012, Ur-Energy notified the NRC of its intent to recover uranium from the Shirley Basin Project using in situ mining techniques. The company anticipates submitting a license amendment request to the NRC in the first quarter of 2014.”
} 

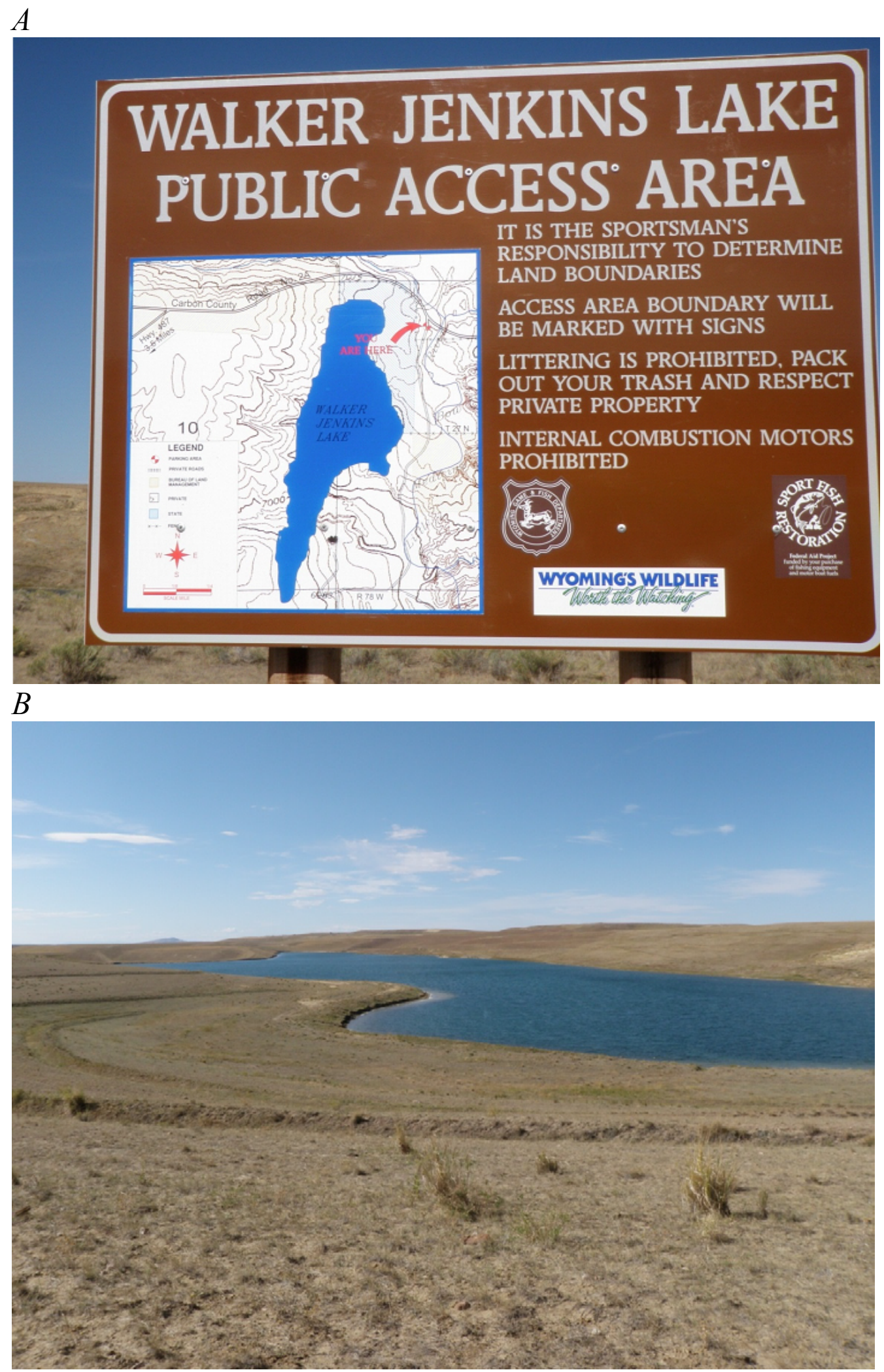

Figure 7. Walker Jenkins Lake, 2009. A. Walker Jenkins Lake Public Access Area sign. B. The lake, a reclaimed and repurposed open-pit uranium mine in the Shirley Basin, southwestern Wyoming. 
Other nearby areas with previously productive mines are the East Shirley Mountains (Ajo and Bald Knob, appendix A), and the Miller Hill area. Neither was of sufficient size or distinction to be defined as a "district" by Gregory and others (2010).

\section{Crooks Gap-Green Mountain Area}

Gregory and others (2010) separate the Crooks Gap-Green Mountain area (plate 1) from the rest of the Great Divide Basin area. Dahlkamp (2010) describes the Crooks Gap area and the Green Mountains areas separately as being within the Great Divide Basin (along with the Sweetwater and the Red Desert areas). However it is defined, the Crooks Gap-Green Mountain area is at the extreme northeastern end of the Great Divide Basin. The most productive portion of the Crooks Gap-Green Mountain area is mostly a few miles north of the boundary of WLCI but there is not a clear boundary between the intensely mineralized area at Crooks Gap-Green Mountain and the rest of the Great Divide Basin. Recent exploration and potential for ISR development has been occurring south of the traditional Crooks Gap-Green Mountain area into the Great Divide Basin (as outlined on Gregory and others, 2010). Even though lode claim data (Causey, 2007, rev. 2011) suggest contiguous blocks of mineralized ground, the Crooks GapGreen Mountain area will be considered separately from the bulk of the Great Divide Basin area.

Uranium was discovered in the Crooks Gap-Green Mountain area in 1954 and mining continued through 1989 (Dahlkamp, 2010). According to the tonnages reported by Gregory and others (2010), the seven productive mines in the Crooks Gap-Green Mountain area produced a total of 4,388,463 tonnes of ore ${ }^{7}$. There is no mention of the ore grade; therefore, the amount of contained uranium cannot be accurately estimated. Dahlkamp (2010) estimated the original resources (in situ and mined) on the order of 40,000 $\mathrm{tU}$, some 8,000 tU of which were produced by 17 underground mines and open pits. Mining grades ranged from 0.12 to 0.25 percent uranium. Using this range of values $6,700,000$ to 3,200,000 tonnes of ore were mined, which is consistent with the value reported by Gregory and others (2010). Dahlkamp (2010) does not list the 17 producing mines (other than Big Eagle Pit, McIntosh Pit, Golden Goose, and Sheep Mountain) so it is not possible to compare each mine directly with Gregory and others' (2010) 7 mines (see footnote 7).

Most of the deposits in the district are roll-front-type uranium mineralization, although there are a few on the northern margin of the district (for example, Sheep Mountain and Big Eagle) where the mineralization is structurally controlled, stratiform, and limb-type (Klingmuller, 1989). In unoxidized ground, pitchblende and coffinite are the principal uranium minerals. In oxidized (near surface) ground there are uranyl phosphates, -silicates, -sulfates, and -vanadates (Dahlkamp, 2010, p. 184).

The major deposits in the Crooks Gap-Green Mountain area include Sheep Mountain Deposit (Dahlkamp, p. 181), Big Eagle Pit (fig. 8), McIntosh Pit, and Golden Goose, all at Crooks Gap, and the Jackpot (also called Round Park or Green Mountain), Phase II and Desert View (together called Pathfinder's 6,900 Trend), and the Jan (or Whiskey Peak) deposits (Dahlkamp, 2010, p. 183).

\footnotetext{
${ }^{7}$ All values are reported here in tonnes of ore. The productive mines are (Gregory and others, 2010): Hazel and Beatrice (21 tonnes), Crooks Gap Mines (2,993,100 tonnes), Green Mountain (474,758 tonnes), Sundog (126 tonnes), Snowball and Pay Dirt (242,574 tonnes), Heald (6,023 tonnes), and Big Eagle (672,315 tonnes). It is not clear exactly how each of these mines corresponds to the entries in the MRDS database.
} 


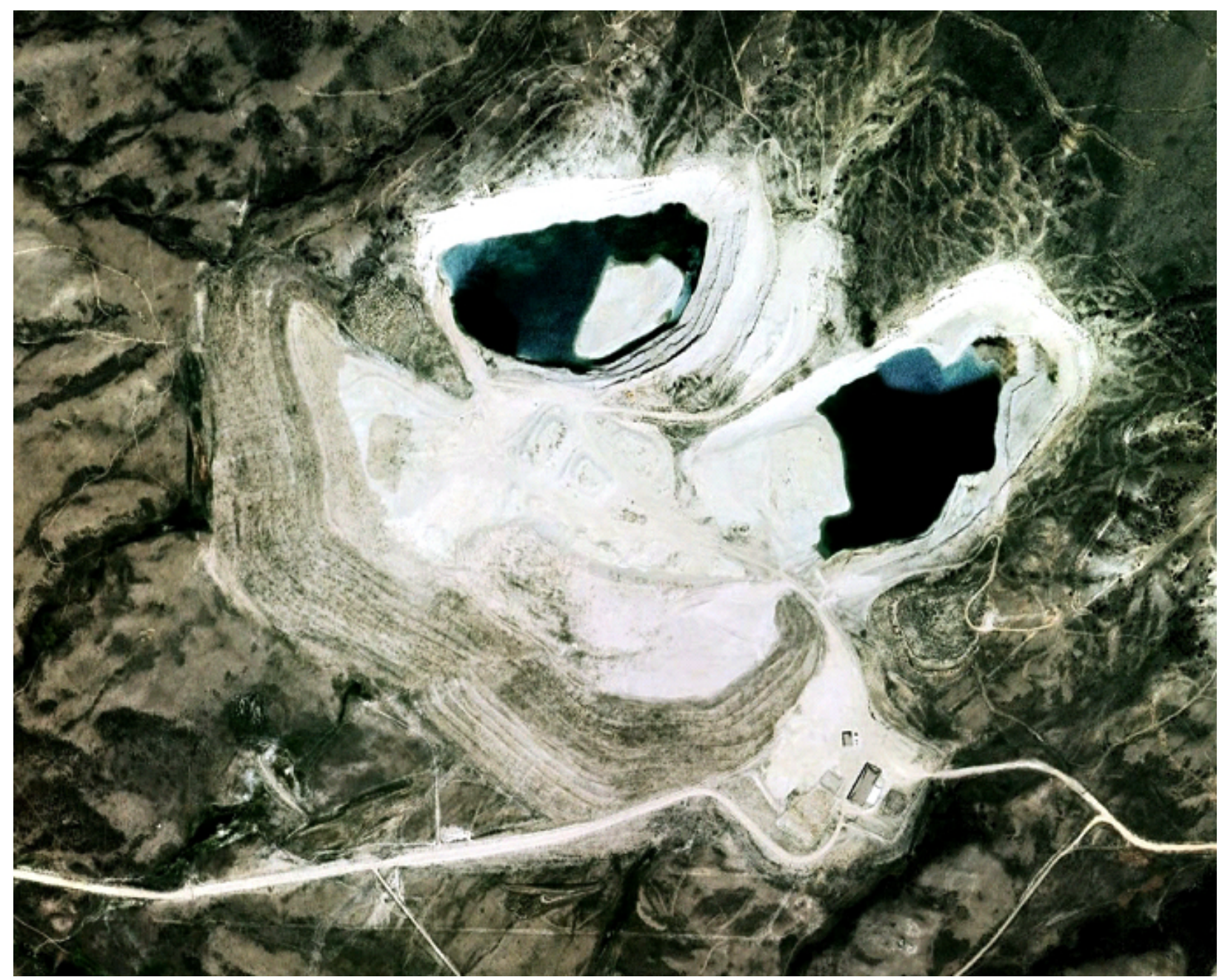

Figure 8. Big Eagle mine, currently not in use. Image from Google Earth, July 17, 2012; date of image unknown.

\section{Great Divide Basin}

The remainder of Great Divide Basin includes Sweetwater (Sweetwater, ENQ, REB deposits), Red Desert (Lost Creek and Lost Soldier deposits), and Bison Basin areas, all described in Dahlkamp (2010, p. 181-192). There are four types of uranium deposits in Great Divide Basin: (1) roll-front sandstone-type deposits, (2) stratiform uranium concentrations (termed limb-type by Klingmuller, 1989), (3) surficial, caliche-type occurrences of schroeckingerite, and (4) uraniferous lignite or subbituminous coal (Dahlkamp, 2010, p. 181). Only the first two types are of economic interest for uranium and will be considered further. Uranium production and established resources are limited to the Sweetwater/Red Desert area in the eastern part of the basin. According to Dahlkamp (2010, p. 181), the entire Great Divide Basin area contains 50,000 tU, of which 40,000 t is attributed to the Crooks Gap-Green Mountain area. Therefore, in spite of the large area covered, Great Divide Basin (excluding Crooks Gap-Green Mountain) is estimated by Dahlkamp to contain only 10,000 tU, including 
about $200 \mathrm{tU}$ already produced. This number is vastly underestimated and, as will be pointed out in this discussion, is probably closer to 24,000 to $30,000 \mathrm{tU}$. Gregory and others (2010) report a total of 2,544,315 tonnes ${ }^{8}$ of ore produced, of which more than 97 percent came from the Sweetwater mine.

The Sweetwater portion of the Great Divide Basin area is located in the central part of the Great Divide Basin and includes the Sweetwater, ENQ, and REB deposits. Original resources (in-situ and mined) of these three properties, in aggregate, were on the order of 10,000 tU at grades between 0.025 and 0.06 percent uranium. Only the Sweetwater deposit was mined, although a large resource remains. From 1981 to 1983, the Sweetwater open-pit mine produced about $500 \mathrm{tU}$ at an average grade of 0.039 percent. Original resources were estimated at 7,300 $\mathrm{tU}$. No resource numbers have been reported for the ENQ. Resources at the REB are 1,500 tU at a grade averaging about 0.06 percent uranium (Dahlkamp, 2010, p. 191).

In the northeastern part of the Great Divide Basin, in the area associated with the Red Desert area, the Lost Soldier deposit reportedly contains 5,642 $\mathrm{tU}$ (computed from Wallis, 2006) to 10,230 tU (Dahlkamp, 2010, p. 191-192) and the Lost Creek deposit contains 7,000 tU at average grade of 0.044 percent (Dahlkamp, 2010, p. 192). The earliest discovery of uranium in sandstones in Wyoming was in 1936 near the surface along Lost Creek, from which schroeckingerite ore was mined intermittently from 1954 to 1966 (Dahlkamp, 2010, p. 192). At the extreme north edge of the Great Divide Basin area is Bison Basin containing a roll-front sandstone type uranium deposit. Uranium was mined conventionally in the 1960s and 1970 s and later, in the 1980s, by in-situ recovery. There is no public record of the actual production. Dahlkamp (2010, p. 192) estimated remaining in-situ resources of about 1,600 tU at grades from 0.04 to 0.06 percent uranium (using a cutoff grade of 0.017 percent uranium).

Finally, in the extreme northwest corner of the Great Divide Basin is the Pard Mine (Harris, 1997; Gregory and others, 2010) which produced 386 tonnes of ore (plate 1). Grade is not given, therefore the amount of contained uranium or $\mathrm{U}_{3} \mathrm{O}_{8}$ is not known.

${ }^{8}$ Gregory and others (2010) report 2,805,198 short tons of which 2,736,120 short tons came from the Sweetwater Mine. Dahlkamp reports 500 tU at 0.039 percent from Sweetwater, or 1,282,051 tonnes production, or half of Gregory and others' value. 


\section{Acknowledgments}

This report is a companion to Biewick and Wilson, 2014. That report contains a complete GIS database from which the maps and plate in this report can be constructed. An enormous thank you to Laura Biewick (U.S. Geological Survey Central Energy Resources Science Center, Denver) for ArcGIS expertise and guidance. Thanks, too, to William D. Heran (USGS Mineral and Environmental Resources Science Center) for field assistance and the first manuscript review. George Breit (USGS Mineral and Environmental Resources Science Center, retired) made many suggestions that substantially improved the report and Robert Gregory, Wyoming State Geological Survey, provided updated information, facts, and figures. 


\section{References Cited}

Anderson, C.L., and Van Pelt, Lori, 2015, Wyoming's uranium drama—Risks, rewards and remorse: Wyoming State Historical Society. Accessed August 18, 2015, at www.wyohistory.org/encyclopedia/wyomings-uranium-drama-risks-rewards-and-remorse.

Beahm, D.L., 2012, Juniper Ridge Uranium Project, Carbon County, Wyoming, USA: 43-101 Mineral Resource Technical Report, prepared for Crosshair Energy Corporation, February 21, 2012, 93 p. Accessed Accessed August 17, 2015, at http://www.energyfuels.com/_resources/Juniper_Ridge_Feb2012.pdf.

Biewick, L.R.H., and Wilson, A.B., 2014, Energy map of southwestern Wyoming, Part B-Oil and gas, oil shale, uranium, and solar: U.S. Geological Survey Data Series 843. Available at http://pubs.usgs.gov/ds/683.

Boberg, W.W., 2010, The nature and development of the Wyoming uranium province: Society of Economic Geologists Special Publication 15, p. 653-674.

Causey, J. D., 2007 [revised 2011], Mining claim activity on Federal land in the United States: U.S. Geological Survey Data Series 290, version 4. Accessed at http://pubs.usgs.gov/ds/2007/290/.

Dahlkamp, F.J., 2010, Uranium deposits of the world—USA and Latin America, Wyoming Basins: SpringerLink, p. 149-207. Accessed July, 2012, at http://www.springerlink.com/content/x74946/?MUD=MP. [Bibliography, p. 381-414 is not available online].

Dribus, J.R., and Nanna, R.F., 1982, National Uranium Resource Evaluation, Rawlins quadrangle, Wyoming and Colorado: U.S. Department of Energy (with Bendix Field Engineering Corporation) report PGJ/F 19(82), 116 p.

ENSR Corporation and Booz Allen \& Hamilton Inc., 2003, Mineral occurrence and development potential report, Rawlins Resource Management Plan Planning Area, prepared for the Bureau of Land Management Rawlins Field Office, 186 p. Accessed at http://www.blm.gov/wy/st/en/ programs/Planning/rmps/rawlins/minerals.print.html.

Finch, W.I., 2003, Uranium-Fuel for nuclear energy 2003: U.S. Geological Survey Bulletin 2179-A, 18 p. Accessed at http://pubs.usgs.gov/bul/b2179-a/B2179-A-508.pdf.

Gregory, R.W., 2015, Wyoming's uranium resources: Wyoming State Geological Survey Summary Report. Accessed August 18, 2015, at www.wsgs.wyo.gov/products/2015-uraniumsummary.pdf.

Gregory, R.W., Jones, R.W., and Cottingham, K.D., 2010, Uranium map of Wyoming: Wyoming State Geological Survey Map Series 94, scale 1:500,000.

Harris, R.E., compiler, 1985, Uranium mines and uranium and thorium occurrences in Wyoming: Geological Survey of Wyoming Open File Report 85-6, 10 p., 1 plate, scale 1:500,000.

Harris, R.E., 1997, Radioactive mineral occurrences in Sublette County, Wyoming: Wyoming State Geological Survey Radioactive Mineral Report RM97-01, 23 p.

Harshman, E.N., 1972, Geology and uranium deposits, Shirley Basin area, Wyoming: U.S. Geological Survey Professional Paper 745, 82 p. Accessed at http://pubs.usgs.gov/pp/0745/report.pdf.

Klingmuller, L.M.L., 1989, The Green Mountain uranium district, central Wyoming-Type locality of solution front limb deposits, in Uranium resources and geology of North America, Proceedings of a Technical Committee Meeting Organized by the International Atomic Energy Agency and held in Saskatoon, Canada, 1-3 September 1987: Vienna, Austria, International 
Atomic Energy Agency IAEA-TECDOC-500, p. 173-190. Accessed at http://wwwpub.iaea.org/MTCD/publications/PDF/te_0500.pdf.

Ludwig, K.R., 1978, Uranium-daughter migration and U/Pb isotope apparent ages of uranium ores, Shirley Basin, Wyoming: Economic Geology, v. 73, no. 1, p. 29-49.

MINOBRAS, 1976, Uranium guidebook for Wyoming: Dana Point, Calif., 63 p. and appendix.

Morris, A.V., and Stanley, D.R. (Morris \& Warchola Inc.), 1982, National Uranium Resource Evaluation, Rock Springs quadrangle, Wyoming and Colorado: Department of Energy (with Bendix Field Engineering Corporation) report PGJ/F 80(82), 42 p.

Strathmore Minerals Corporation, 2006, Strathmore Minerals acquires near-surface uranium deposit amenable to conventional mining: News release, Tues., Jul 18, 2006. Accessed August 17, 2015, at http://www.transworldnews.com/NewsStory.aspx?id=9857.

Strathmore Minerals Corporation, 2010, Strathmore to sell Juniper Ridge, Wyoming, uranium development project to Crosshair Exploration: News release, Nov. 1, 2010. August 17, 2015, at http:/finance.yahoo.com/news/Strathmore-to-Sell-Juniper-iw-2154398636.html?x=0\&.v=1.

U.S. Bureau of Mines, 1997, A dictionary of mining, mineral, and related terms, 2d ed.: Falls Church, Va., American Geological Institute, 646 p.

U.S. Department of Energy, 1980, An assessment report of uranium in the United States of America (with Bendix Field Engineering Corporation): Report GJO 111(80), 147 p.

U.S. Department of the Interior Bureau of Land Management (BLM), 2012a, Lost Creek in situ uranium recovery project. Accessed July 17, 2012, at http://www.blm.gov/wy/st/en/info/NEPA/documents/rfo/lostcreek.html.

U.S. Department of the Interior Bureau of Land Management (BLM), 2012b, Plan of operations. Accessed July 17, 2012, at http://www.blm.gov/wy/st/en/info/NEPA/documents/rfo/ juniper_ridge.html.

U.S. Department of the Interior Bureau of Land Management (BLM), 2012c, BLM Rawlins Field Office seeking comment on the Juniper Ridge uranium project. Accessed July 17, 2012, at http://www.blm.gov/wy/st/en/info/news_room/2012/may/10rfo-juniper.html.

U.S. Geological Survey, 1980, Principles of a resource/reserve classification for minerals: U.S. Geological Survey Circular 831, 5 p.

U.S. Geological Survey, 2010, Divisions of geologic time-Major chronostratigraphic and geochronologic units: Fact Sheet 2010-3059, 2 p.

U.S. Geological Survey, 2013, Mineral Resources Data System (new MRDS). Accessed at http://mrdata.usgs.gov/mrds/ [external—data subset] or https://igskaccgvmmrds4.cr.usgs.gov:8443/ords/f?p=130: [internal—full records]

U.S. Nuclear Regulatory Commission, 2012a, Locations of uranium recovery facilities. Accessed July 17, 2012, at http://www.nrc.gov/info-finder/materials/uranium/index.html.

U.S. Nuclear Regulatory Commission, 2012b, JAB \& Antelope Site-Review deferred. Accessed August 17, 2015, at http://www.nrc.gov/materials/uranium-recovery/licenseapps/jab-antelope.html.

U.S. Nuclear Regulatory Commission, 2012c, 05/01/2008, Summary of meeting with Wildhorse Energy to discuss Wildhorse Energy's (Wildhorse's) planned West Alkali Creek uranium recovery site. Accessed July 17, 2012, at http://pbadupws.nrc.gov/docs/ML0816/ ML081610706.html.

U.S. Nuclear Regulatory Commission, 2012d, License applications for new uranium recovery facilities, expansions, restarts, and renewals. Accessed July 17, 2012, at http://www.nrc.gov/materials/uranium-recovery/license-apps.html. 
Uranium One Inc., 2012, Willow Creek Mine: Company website. Accessed Jan. 2, 2013, at http://www.uranium1.com/index.php/en/mining-operations/united-states/willow-creek.

Ur-Energy Inc., 2013, Ur-Energy begins production operations at Lost Creek, News release, Aug. 2, 2013. Accessed Sept. 11, 2013, at http://www.ur-energy.com/2013-news-releases/.

Vine, J.D., and Prichard, G.E., 1959, Geology and uranium occurrences in the Miller Hill area, Carbon County, Wyoming: U.S. Geological Survey Bulletin 1074-F, p. 201-238.

Wallis, C.S., 2006, Technical report on the Lost Soldier Project, Wyoming: Prepared by Roscoe Postle Associates for Ur-Energy Inc., dated July 10, 2006 [NI-43-101 filed with www.sedar.com on August 4, 2006.]

Wilson, A.B., Klein, T.L., and Heran, W.D., 2001, Database and simplified geology for mineralized areas, claims, mines, and prospects in Wyoming: U.S. Geological Survey OpenFile Report 01-0497. Accessed at http://pubs.usgs.gov/of/2001/ofr-01-0497/.

WISE (World Information Service on Energy) Uranium Project, 2012, New uranium mining projects, Wyoming, USA. Accessed July 17, 2012, at http://www.wise-uranium.org/ upusawy.html.

Wyoming Mining Association, 2012, A citizen's guide to uranium mining, February, 2012, 8 p. Accessed July 2012 at http://www.wma-minelife.com/uranium/Citizens_Guide_Uranium/ Citizens_Guide_Uranium_02_2012.pdf.

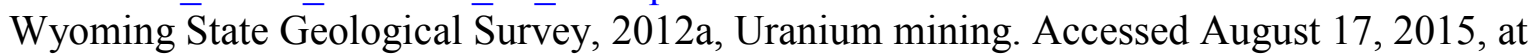
http://www.wsgs.wyo.gov/energy/uranium-mining.aspx.

Wyoming State Geological Survey, 2012b, Historic $\mathrm{U}_{3} \mathrm{O}_{8}$ production. Accessed May, 2012, at http://www.wsgs.uwyo.edu/AboutWSGS/uranium.aspx. \{dead link\}

Wyoming State Geological Survey, 2012c, Uranium. Accessed 13 July 2012, at http://www.wsgs.uwyo.edu/Research/Energy/Uranium.aspx. \{dead link\}

Wyoming State Geological Survey, 2012d, Uranium geology. Accessed August 17, 2015, at http://www.wsgs.wyo.gov/energy/uranium-geology.aspx.

Wyoming State Geological Survey, 2012e, Uranium deposits. Accessed August 17, 2015, at http://www.wsgs.wyo.gov/energy/uranium-deposits.aspx. 


\section{Glossary}

Total endowment Tons of uranium in the ground before mining. Ideally the total tons of ore and the estimated grade are known.

Mining claim Tract of public land to which an entity has claimed rights to the minerals. Most commonly an unpatented claim to which the mineral holder does not own the ground. Patented claims are lands to which ownership has been transferred to the claimant.

Original resource The amount of the resource before production (U.S. Geological Survey, 1980).

Reserve The portion of an identified resource that is valuable and from which a usable mineral can be economically and legally extracted at the time of determination; essentially, the recoverable ore (U.S. Geological Survey, 1980).

Resource A concentration of a naturally occurring commodity in such form and amount that economic extraction of that commodity from the concentration is currently or potentially feasible (U.S. Geological Survey, 1980).

Undiscovered resource Resources, the existence of which are only postulated, comprising deposits that are separate from identified resources. Undiscovered resources may be postulated in deposits of such grade and physical location as to render them economic, marginally economic, or subeconomic (U.S. Geological Survey, 1980).

Yellow cake A uranium concentrate (a precipitate in a form of $\mathrm{U}_{3} \mathrm{O}_{8}$ ) produced by milling (U.S. Bureau of Mines, 1997). 


\title{
Appendix A. Complete U.S. Geological Survey Mineral Resources Data System Records for All Primary Uranium Sites and Districts in Wyoming Landscape Conservation Initiative, Arranged by County
}

AppendixA_WLCI_MRDS_uranium.pdf, included, is composed of several .pdf files.

Any errors or omissions should be brought to the author's attention so that changes can be made to the original database.

Full records are available to internal USGS users at

https://igskaccgvmmrds4.cr.usgs.gov:8443/ords/f?p=130:. A subset of this dataset is served to the public at http://mrdata.usgs.gov/mineral-resources/mrds-us.html. The internal dataset is the source of the data in the ArcGIS (Biewick and Wilson, 2014).

For cross referencing purposes, indexes to the contents of the .pdf file are in the accompanying .xls files.

The number following the county name is the number of uranium records in that county.

\author{
Carbon_157.pdf \\ ApAa_Carbon_157.xls \\ Sweetwater_155.pdf \\ ApAb_Sweetwater_155.xls \\ Sublette_22.pdf \\ ApAc_Sublette_22.xls \\ Lincoln_24.pdf \\ ApAd_Lincoln_24. xls \\ Uinta_4.pdf \\ ApAe_Uinta_4. xls \\ Fremont_CrooksGap_110.pdf \\ ApAf_Fremont_CrooksGap_110.xls
}

\section{Appendix B. Metadata for the U.S. Geological Survey Mineral Resources Data System Records in Wyoming Landscape Conservation Initiative}

